\title{
Comparison of HELIOS-2.1 and SCALE-6.1 codes on pin-cell model
}

Sabina Maharramova a, b*, William Beere c, Knut Eitrheim c, Ole Reistad ${ }^{\text {d, }}$, Tord Walderhaug c

\author{
${ }^{a}$ Department of Physics, University of Oslo, P.O. box 1048 Blindern, 0316 Oslo, Norway \\ ${ }^{\mathrm{b}}$ National Nuclear Research Centre, Insaatchilar ave. 4, AZ 1143, Baku, Azerbaijan \\ ${ }^{\mathrm{c}}$ Institute for Energy Technology, P.O. box 173, 1751 Halden, Norway \\ ${ }^{\mathrm{d}}$ Institute for Energy Technology, P.O. box 40, 2027 Kjeller, Norway
}

*Corresponding author: s.a.maharramova@fys.uio.no

\begin{abstract}
Deterministic HELIOS-2.1 and SCALE-6.1 codes are compared using pin-cell models for light water reactor (LWR) and heavy water reactor (HWR) cases. The main objective of this study is to identify the origins of any discrepancies between compared codes. The infinite multiplication factor $\mathrm{k}_{\mathrm{inf}}$, flux distribution, absorption, fission, production reaction rates, and burn-up dependent concentrations of major fuel isotopes, are investigated herein and compared.

Comparison of $\mathrm{k}_{\text {inf }}$ has shown that the codes are in good agreement for both the LWR and HWR cases. The codes showed differences in the isotope number density of up to $6 \%$ in the case of prominent isotopes, and for ${ }^{235} \mathrm{U}$ and ${ }^{239} \mathrm{Pu}$ at $60 \mathrm{GWd} / \mathrm{tU}$ in the LWR case. These differences were, approximately $20 \%$ for ${ }^{235} \mathrm{U}$ and $30 \%$ for ${ }^{239} \mathrm{Pu}$ in the HWR case.

It is concluded that these discrepancies are attributed to differences in the modelling of the thermalisation process in the HWR case. This needs to be investigated further to determine the root cause. Possible causes could be the neutron group structure, cross section condensation, treatment of up-scatter, angle dependence of scatter, and spatial homogenisation during source iterations.
\end{abstract}

Key words: HELIOS-2.1, SCALE-6.1, LWR, HWR, pin-cell model

\section{Introduction}

Many reactor simulation and modelling codes have been developed to predict fuel depletion during the nuclear fuel cycle since the operation of the first reactors. These codes are very important for safe and efficient operation of research reactors and power plants. Multiple benchmark studies have been conducted to assess the accuracy of the depletion codes used to predict the isotopic composition of the spent fuel (Brady, 1992; Brady et al., 1996).

The main objective of this study is the determination of the isotopic distribution of selected actinides at high burn-ups, up to 60GWd/tU. A secondary purpose is to compare the HELIOS- 
2.1 and SCALE-6.1 codes, in order to identify systematic differences between these two deterministic codes, and to validate the SCALE/ TRITON code for the building the specific cross section libraries for use in the Halden boiling water reactor (HBWR).

This comparison has been made with single fuel region models. The infinite multiplication

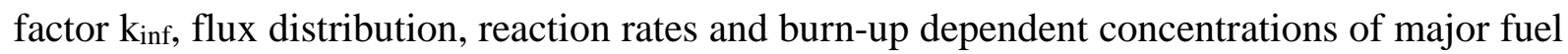
isotopes were calculated and compared in this study in order to validate the SCALE code (using the TRITON module) for future use with the Halden reactor.

HELIOS and SCALE codes have also been benchmarked and applied by previous investigators (Brady et al., 1996; OECD/NEA, 2000). HELIOS-1.4 and SCALE-4.4 codes were used on the VENUS-2 MOX (a blind) benchmark study (OECD/NEA, 2000). Contrary to previous benchmarks, this benchmark was based on experimental results. The main objective of the benchmark was to validate and compare the nuclear data sets and codes used for MOX fuel modelling in accordance to the NEA member states. Ten institutions participated in the assessment of this benchmark, and deterministic (HELIOS, WIMS-D and SCALE/XSDRNPM) and Monte Carlo (MCNP-4B, MVP and MCU-B) methods were applied. Furthermore, $\mathrm{k}_{\text {inf }}$ and reaction rates from the cell calculations and $k_{\text {eff }}$ and pin power (fission rate) from the core calculations were investigated and compared with the experimental values. Most of elicited results from the deterministic codes showed that the deviation of $\mathrm{k}_{\text {inf }}$ from the average values was approximately $0.5 \%$, while Monte Carlo based codes yielded results with a deviation that was less than $0.2 \%$. All reported $k_{\text {eff }}$ values showed good agreement with the experimental value. The uncertainty in the experimental determination of this value was $0.5 \%$. The calculated pin power results from both the deterministic and Monte Carlo methods showed excellent agreement with the experimental values.

In another study, the HELIOS-1.5 and SCALE-4.4a codes were compared for nuclide inventory calculations of spent fuel from VVER-1000 in Kozloduy NPP, Bulgaria (Kamenov and Hristov, 2007). Calculated data from SCALE-4.4a was compared with fuel supplier data and with data calculated by using the HELIOS-1.5 code. In addition to the standard $17 \times 17$ ORIGEN-S libraries, a specific library for VVER fuel was developed for the Kozloduy NPP and was verified against the standard $17 \times 17$ library and HELIOS-1.5 calculated data. According to this study, it was concluded that ORIGEN-S can provide reliable isotope concentration estimations, if a specific library is used for each fuel type.

A study was performed at the Los Alamos National Laboratory to explore the accuracy of reactor analysis codes (HELIOS-1.4, ORIGEN2 and Monteburns-3.01) in calculating ${ }^{241} \mathrm{Am}$ and ${ }^{243} \mathrm{Am}$ concentrations in spent fuel from light water reactors (PWR, BWR, VVER) (Charlton, 2000). Calculated concentrations were compared to measured values from the literature for PWR fuel from Mihama Unit 3, Garigliano BWR fuel and VVER-440 fuel. It was determined that all codes performed well for the Mihama Unit 3 and Garigliano measurements, while HELIOS and Monteburns codes both demonstrated good ability to calculate these isotopes for VVER fuel. However, ORIGEN2 was insufficient for VVER-440 measurements.

This study is organised as follows: the HELIOS-2.1 and SCALE-6.1 codes are briefly described in Section 2. Section 3 presents the pin-cell model. The results from the HELIOS and SCALE 
code comparisons and the relevant discussion are presented in Section 4. Finally, Section 5 concludes the study.

\section{Code descriptions}

HELIOS-2.1 and SCALE-6.1 versions were used to perform depletion calculations in this study. Depletion calculations were modelled using $0.1 \mathrm{GWd} / \mathrm{tU}$ steps within the range of 0 to $0.5 \mathrm{GWd} / \mathrm{tU}$, and $1 \mathrm{GWd} / \mathrm{tU}$ steps within the range of 0.5 to $60 \mathrm{GWd} / \mathrm{tU}$ for both HELIOS-2.1 and SCALE-6.1. As described below, the calculations were performed by using the same data library (ENDF/B-VII.0), but different neutron energy group structures. HELIOS-2.1 used the 177-energy-group, while SCALE-6.1 used the 238-energy-group.

\subsection{HELIOS-2.1}

HELIOS-2.1 is a deterministic neutron and gamma transport code designed by Studsvik Scandpower to perform nuclear fuel analyses (Studsvik, 2012). HELIOS-2.1 is capable of analysing nuclear fuel designs for different types of nuclear power plants and experimental reactors.

The HELIOS-2.1 code comes with default nuclear data libraries, which are based on ENDF/BVII.0 data files and are available in several group structures ranging from the 49-177 neutron energy groups (Chadwick et al., 2006). The base nuclear data library uses the 177 neutron and the 48 photon energy groups. The library contains neutron data for 360 isotopes, including 178 fission products and 95 resonance isotopes. The photon cross section data is available for 356 isotopes. Previous HELIOS versions (older than HELIOS-2.0) were available in two different sets of libraries, that is, the libraries in which the ${ }^{238} \mathrm{U}$ absorption cross section has been adjusted (reduced) by $3.4 \%$ and in unadjusted libraries. The adjusted libraries were added to yield better agreement for ${ }^{238} \mathrm{U}$ in LWR.

The main cross section processing was performed with the NJOY code (MacFarlane and Kahler, 2010). In this study, the current coupling and collision probabilities (CCCP) method is used for transport calculations. HELIOS-2.1 uses an intermediate resonance approximation (IR method) for homogeneous systems and the subgroup method for heterogeneous systems for resonance treatments.

\subsection{SCALE-6.1}

The SCALE-6.1 code system, developed and maintained by the Oak Ridge National Laboratory (ORNL) in the USA, is a multi-purpose computer code for nuclear safety analysis and design (ORNL, 2011). SCALE is a package containing numerous sets of codes with a broad range of functions and capabilities.

Multi-group cross section libraries and pointwise continuous energy libraries (ENDF/B-V, ENDF/B-VI.8 and ENDF/B-VII.0) are distributed with the SCALE-6.1 code. There are various energy group structures ranging from 44-238 neutron energy groups available in SCALE. The 
238-group ENDF/B-VII.0 neutron library is used by SCALE-6.1 in this study. The 238-group ENDF/B-VII.0 library contains data for 417 nuclides and has 148 fast and 90 thermal groups, similar to the 238-group ENDF/B-V and ENDF/B-VI.8 libraries.

This research is based on the capabilities of the TRITON module (Jessee and DeHart, 2011). During the simulation, TRITON deploys the cross-section processing code CENTRM, the transport code NEWT and the isotopic depletion code ORIGEN-S. Cross section processing is carried out by CENTRM/PMC based on the ENDF/B-VII.0 238-group neutron library. CENTRM computes a continuous-energy neutron spectrum by using a one-dimensional solution to the Boltzmann transport equation (Williams and Hollenbach, 2011). PMC generates problem-dependent multi-group cross-sections from the AMPX multi-group cross-section library. Moreover, NEWT is a two-dimensional deterministic code used for neutron transport calculation (Jessee and DeHart, 2011). NEWT employs an extended step characteristic (ESC) approach, which provides a unique capability for discrete ordinates calculations on an arbitrary grid. ORIGEN-S has been developed as the depletion and decay module in the SCALE code system (Gauld, 2011). It calculates nuclide compositions and the radioactivity of fission products, activation products, and products of heavy metal transmutation.

\section{Pin-cell model description}

An infinite reactor system with only one fuel region is chosen in this study to simplify the comparison of the codes. It was assumed that there was no leakage in the system. LWR and HWR cases are studied with this pin-cell model. Table 1 shows the fuel composition and pincell dimensions used by the HELIOS-2.1 and SCALE-6.1 codes for the LWR and HWR cases.

Table 1. Pin-cell specifications

\begin{tabular}{|l|c|c|}
\hline \multicolumn{1}{|c|}{ Parameter } & LWR & HWR \\
\hline Pin pitch radius $(\mathrm{cm})$ & 1.4 & 4.3 \\
\hline Fuel pellet radius $(\mathrm{cm})$ & 0.5 & 0.5 \\
\hline Fuel pellet material & $\mathrm{UO}_{2}$ & $\mathrm{UO}_{2}$ \\
\hline Fuel density $\left(\mathrm{g} / \mathrm{cm}^{3}\right)$ & 10.96 & 10.96 \\
\hline Fuel enrichment $(\mathrm{w} / \mathrm{o})$ & 6.0 & 6.0 \\
\hline Fuel temperature $(\mathrm{K})$ & 300 & 300 \\
\hline Cladding radius $(\mathrm{cm})$ & 0.6 & 0.6 \\
\hline Cladding material & $\mathrm{Zr}-2$ & $\mathrm{Zr}-2$ \\
\hline Cladding density $\left(\mathrm{g} / \mathrm{cm}^{3}\right)$ & 8.4 & 8.4 \\
\hline Moderator material & $\mathrm{H}_{2} \mathrm{O}$ & $\mathrm{D}_{2} \mathrm{O}$ \\
\hline Moderator density $\left(\mathrm{g} / \mathrm{cm}^{3}\right)$ & 0.75 & 1.1 \\
\hline Power $(\mathrm{W} / \mathrm{g})$ & 40 & 40 \\
\hline
\end{tabular}

Figure 1 and 2 display the HELIOS-2.1 and SCALE-6.1 models for the pin-cell geometry that were used in the modelling of the LWR and HWR cases. The figures show the fuel, cladding and moderator regions in each model. The colour key scheme used in figures 1 and 2 for HELIOS-2.1 and SCALE-6.1 is listed in table 2.

Table 2. Figures colour key

\begin{tabular}{|c|c|c|}
\hline Regions & HELIOS-2.1 & SCALE-6.1 \\
\hline
\end{tabular}




\begin{tabular}{|c|c|c|}
\hline Fuel & Light blue & Red \\
\hline Clad & Dark green & Light green \\
\hline Moderator & Pink & Dark blue \\
\hline
\end{tabular}

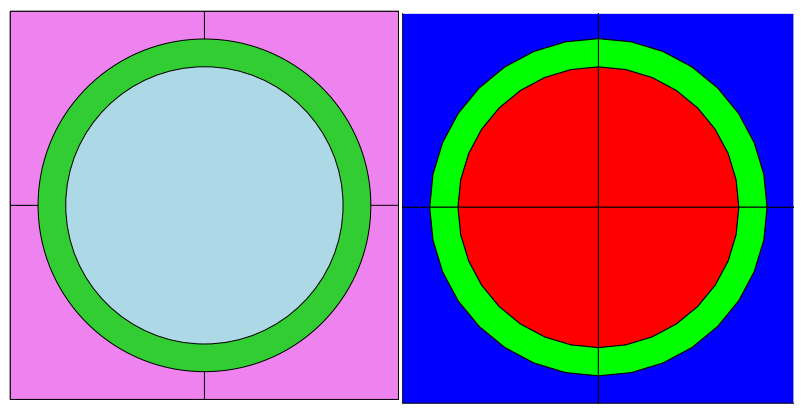
a. HELIOS model
b. SCALE/TRITON model

Figure 1. LWR pin-cell model
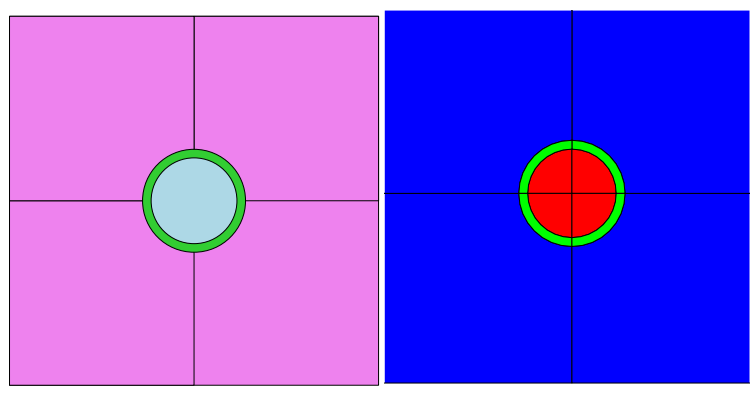

a. HELIOS model b. SCALE/TRITON model

Figure 2. HWR pin-cell model

\section{Results and Discussion}

\subsection{Infinite multiplication factor}

The ORNL HELIOS-1.4 $\mathrm{k}_{\text {inf }}$ results from the VENUS-2 benchmark study were reproduced and compared with HELIOS-2.1 results (Ellis, 2001). Three pin-cell models have been studied and two main parameters, namely, the infinite multiplication factor, $\mathrm{k}_{\text {inf, }}$ and reaction rates were investigated in the VENUS-2 experiment. Two cells fuelled with $3.3 \% \mathrm{UO}_{2}$ and $4.0 \% \mathrm{UO}_{2}$ enriched with ${ }^{235} \mathrm{U}$, and one cell fuelled with MOX enriched with $2.0 \%{ }^{235} \mathrm{U}$ and $2.7 \%$ high quality plutonium were used herein. The comparison results are listed in table 3.

Table 3. Comparison of $\mathrm{k}_{\text {inf }}$ estimated using HELIOS-2.1 and HELIOS-1.4 (VENUS-2)

\begin{tabular}{|c|c|c|c|c|}
\hline Method & Library & $\mathrm{UO}_{2} 3.3 \%$ & $\mathrm{UO}_{2} 4.0 \%$ & MOX \\
\hline HELIOS-1.4 (190g) & ENDF/B-VI.1 & 1.4084 & 1.3433 & 1.2625 \\
\hline
\end{tabular}




\begin{tabular}{|l|l|c|c|c|}
\hline HELIOS-2.1 (177g) & ENDF/B-VII.0 & 1.4094 & 1.3432 & 1.2651 \\
\hline *Difference (\%) & & 0.071 & -0.007 & 0.206 \\
\hline
\end{tabular}

The minor difference between the HELIOS-1.4 and HELIOS-2.1 results comes mainly from the differences in the nuclear data libraries and energy groups (table 2). HELIOS-1.4 used the 190-group adjusted ENDF/B-VI.1 library (hy190n48g110a.dat), while the HELIOS-2.1 used the 177-group ENDF/B-VII.0 library (hy177n48g201.dat). The latter yielded higher kinf values for $3.3 \% \mathrm{UO}_{2}$ and $\mathrm{MOX}$ cells than the former $\left(0.071 \%\right.$ for $3.3 \% \mathrm{UO}_{2}$ and $0.206 \%$ for the $\mathrm{MOX}$ cell) and similar results for the $4.0 \% \mathrm{UO}_{2}$ cell (-0.007\%).

Comparison of $\mathrm{k}_{\mathrm{inf}}$ has shown that despite of the differences on nuclear data libraries and energy groups between the two HELIOS versions, the results are similar and the difference is less than $0.3 \%$.

\subsubsection{LWR and HWR cases}

HELIOS-2.1 and SCALE-6.1 calculated $k_{\text {inf }}$ values at different burn-ups are compared on the pin-cell model for LWR and HWR cases. The results of the $k_{\text {inf }}$ comparisons for the LWR case are presented in tables 4 and 5 for the HWR case. The initial xenon concentration is assumed to be zero during the calculations.

Table 4. Comparisons of $k_{\text {inf }}$ estimated using the HELIOS-2.1 and SCALE-6.1 codes in the LWR case

\begin{tabular}{|c|c|c|c|}
\hline $\begin{array}{c}\text { Burnup } \\
(\mathrm{GWd} / \mathrm{tU})\end{array}$ & HELIOS-2.1 & SCALE-6.1 & *Difference (\%) \\
\hline 0 & 1.3389 & 1.3527 & 1.03 \\
\hline 10 & 1.1946 & 1.2092 & 1.22 \\
\hline 20 & 1.1134 & 1.1279 & 1.30 \\
\hline 30 & 1.0490 & 1.0637 & 1.40 \\
\hline 40 & 0.9942 & 1.0080 & 1.39 \\
\hline 50 & 0.9465 & 0.9601 & 1.44 \\
\hline 60 & 0.9055 & 0.9191 & 1.50 \\
\hline$*\left(\mathrm{k}_{\text {SCALE }} / \mathrm{k}_{\text {HELIOS-1 }}\right) \times 100$ & &
\end{tabular}

Table 4 shows that the differences in $k_{\text {inf }}$ between the codes are approximately equal to $1 \%$ for fresh fuel, it increases with depletion, and that is approximately equal to $1.5 \%$ at $60 \mathrm{GWd} / \mathrm{tU}$ in the LWR case.

Table 5. Comparisons of $\mathrm{k}_{\mathrm{inf}}$ estimated using the HELIOS-2.1 and SCALE-6.1 codes in the HWR case

\begin{tabular}{|c|c|c|c|}
\hline $\begin{array}{c}\text { Burnup } \\
(\mathrm{GWd} / \mathrm{tU})\end{array}$ & HELIOS-2.1 & SCALE-6.1 & *Difference (\%) \\
\hline 0 & 1.6812 & 1.6960 & 0.88 \\
\hline 10 & 1.5296 & 1.5495 & 1.30 \\
\hline
\end{tabular}




\begin{tabular}{|c|c|c|c|}
\hline 20 & 1.4401 & 1.4650 & 1.73 \\
\hline 30 & 1.3461 & 1.3707 & 1.83 \\
\hline 40 & 1.2382 & 1.2595 & 1.72 \\
\hline 50 & 1.1073 & 1.1204 & 1.18 \\
\hline 60 & 0.9539 & 0.9585 & 0.48 \\
\hline
\end{tabular}

$*\left(\mathrm{k}_{\text {SCALE }} / \mathrm{k}_{\text {HELIOS }}-1\right) \times 100$

The $\mathrm{k}_{\text {inf }}$ comparison based on the two codes shows that the calculated $\mathrm{k}_{\text {inf }}$ values by SCALE6.1 are slightly higher than those calculated by HELIOS-2.1 in both the LWR and HWR cases, according to tables 4 and 5. In the HWR case, the difference between codes is less than $1 \%$ for fresh fuel, then it increases up to $1.8 \%$ (at $30 \mathrm{GWd} / \mathrm{tU}$ ), and reduces to $0.5 \%$ at $60 \mathrm{GWd} / \mathrm{tU}$ according to table 5 .

Comparison of the calculated $k_{\text {inf }}$ values for HELIOS-2.1 and SCALE-6.1 at different burn-ups has shown that the difference between these deterministic codes is within an acceptable range compared to previous studies. The documented increase of the difference up to $2 \%$ at 30 $\mathrm{GWd} / \mathrm{tU}$, and the decrease to $0.5 \%$ requires more investigation for the HWR case.

\subsection{Flux distribution}

The flux distribution was presented at two burn-up steps in figure 3 for the LWR case. The results from HELIOS-2.1 and SCALE-6.1 show similar behaviours at fast and intermediate neutron energy regions, because both codes have similar energy group numbers and structures. The number of energy groups in the resonance region in SCALE-6.1 is two times the number of HELIOS-2.1, which results in an increased number of depressions in the case of SCALE-6.1 compared to HELIOS-2.1. HELIOS-2.1 has larger depressions in slow and epithermal neutron regions, especially at $60 \mathrm{GWd} / \mathrm{tU}$. In the thermal neutron region both codes have fewer depressions, but the difference between them is significant at low compared to high burn-ups (figure $3 \mathrm{a}, \mathrm{b}$ ).

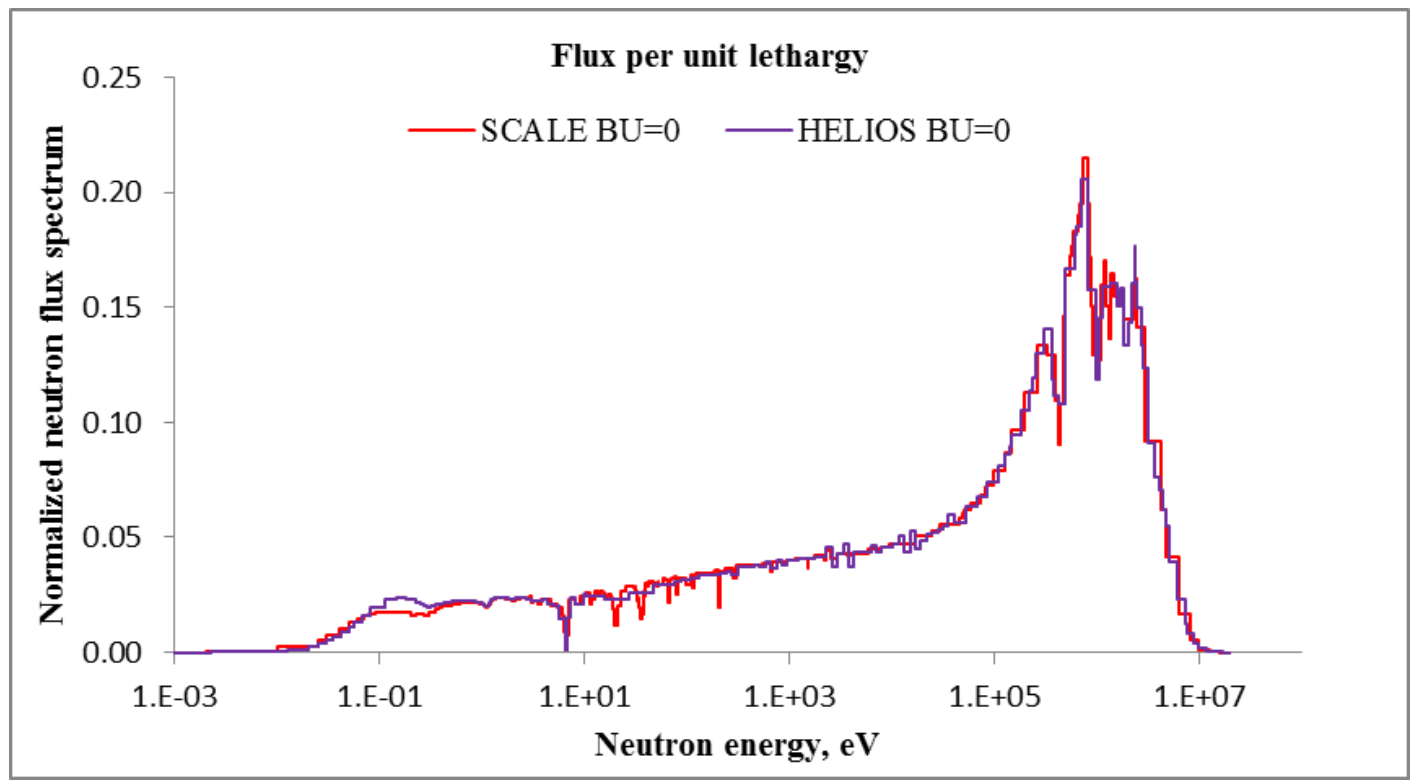

a) Flux distribution for fresh fuel 


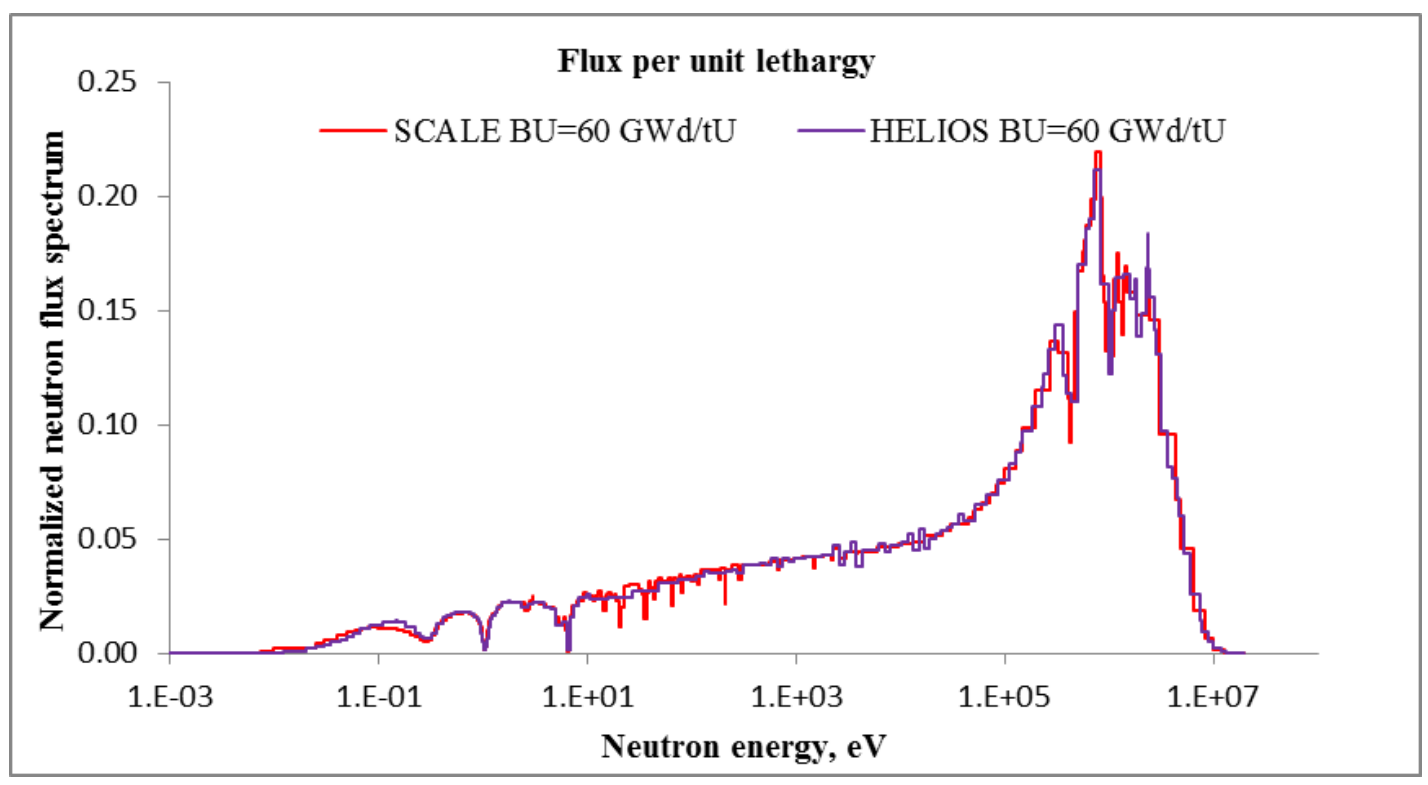

b) Flux distribution at $60 \mathrm{GWd} / \mathrm{tU}$

Figure 3. Flux distributions in fuel regions in the LWR case

A heavy water reactor has a much softer neutron spectrum compared to a light water reactor spectrum (figure $4 \mathrm{a}, \mathrm{b}$ ). Different numbers and structures of neutron energy groups lead to differences in the HWR flux distribution as well. Similar depressions are seen in the fast neutron and resonance regions. SCALE-6.1 has more and larger depressions in the slow neutron region for fresh fuel and at $60 \mathrm{GWd} / \mathrm{tU}$. Both codes show larger depressions in the thermal region. Another reason for these depressions can be attributed to the resonance neutron capture by cladding (zirconium isotopes).

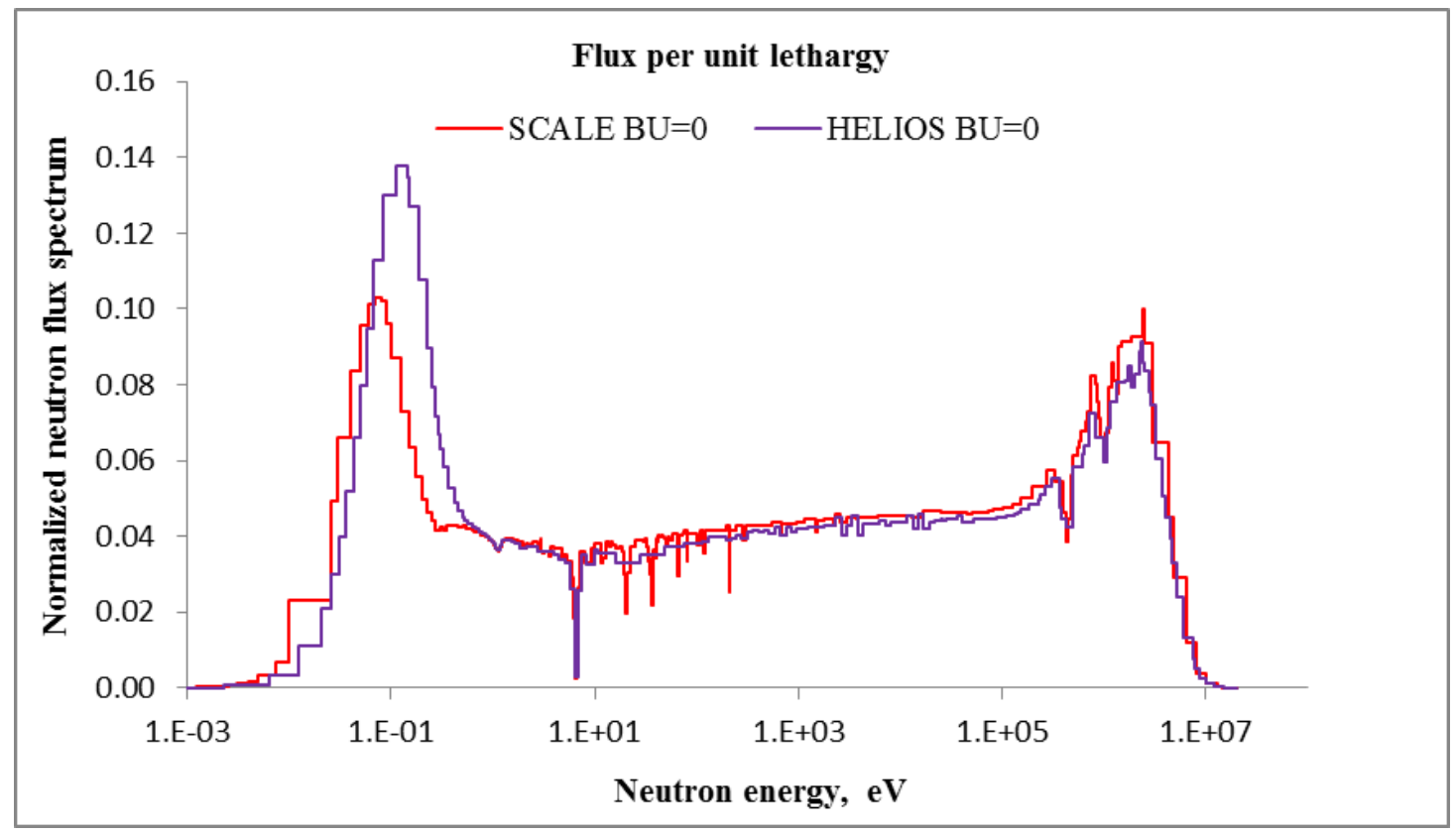


a) Flux distribution for fresh fuel

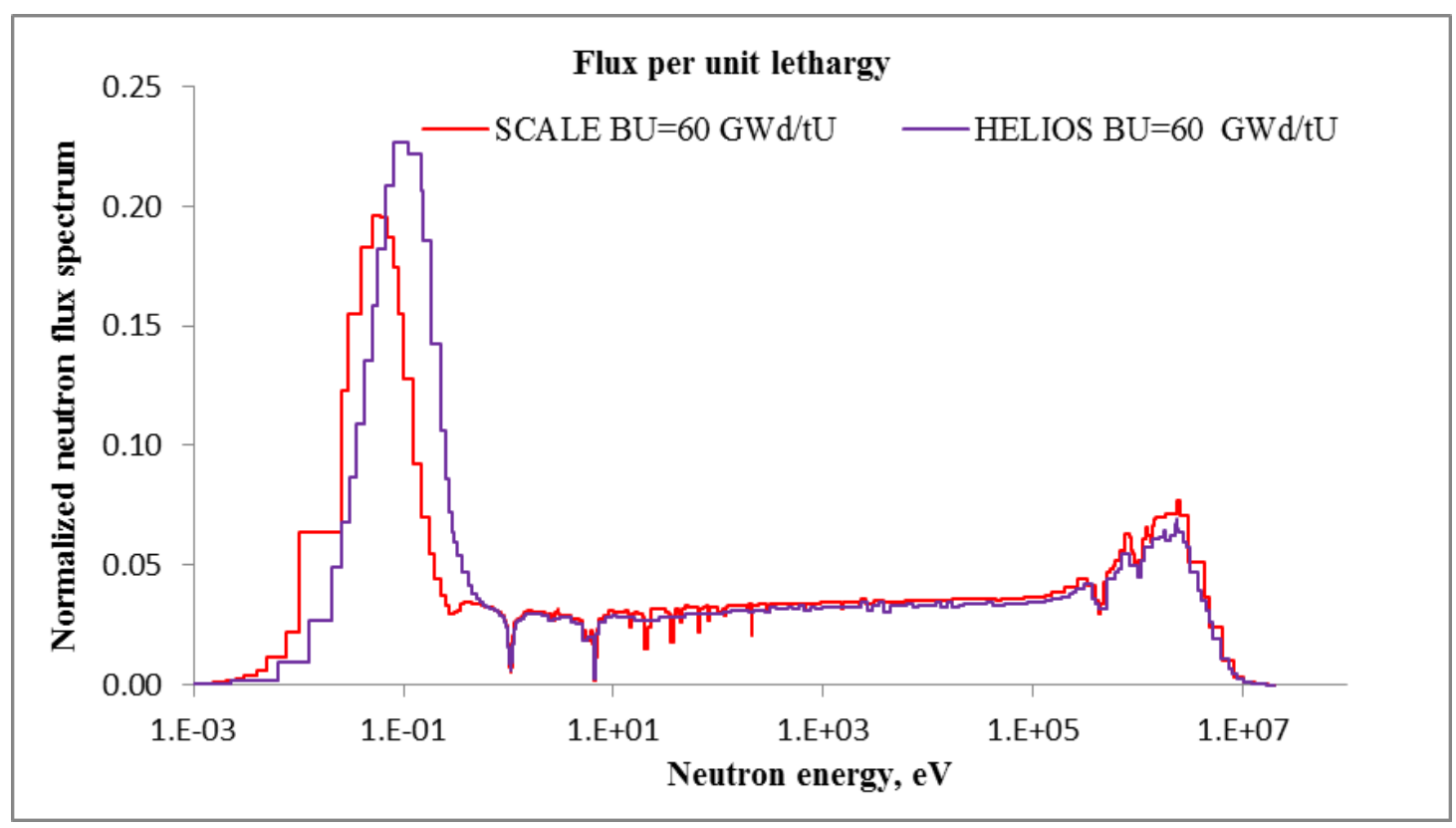

b) Flux distribution at $60 \mathrm{GWd} / \mathrm{tU}$

Figure 4. Flux distributions in fuel regions in the HWR case

It is concluded that, the discrepancies observed in the LWR and HWR flux distributions might be due to the different numbers and structures of the neutron energy groups. In fast neutron regions, the codes have a similar number of groups, but in the resonance and thermal regions, SCALE-6.1 has more energy groups compared to HELIOS-2.1.

The differences observed in the flux distribution have led to the investigation of the reaction rates.

\subsection{Reaction Rates}

Absorption, fission, and production reaction rates per isotope were calculated both in HELIOS2.1 and SCALE-6.1 for the LWR and HWR cases. The calculated results are demonstrated for fresh fuel and for depleted fuel at $60 \mathrm{GWd} / \mathrm{tU}$.

\subsubsection{LWR case}

Fresh fuel contains only uranium isotopes, but the codes consider that there is a trace amount of plutonium isotopes in fresh fuel and show how it will be treated by the codes. Absorption, fission, and production rates per atom were calculated and presented in table 6 for fresh fuel and in table 7 for depleted fuel. The comparison results are listed in table 8.

Table 6. Comparison of calculated reaction rates using HELIOS-2.1 and SCALE-6.1 for fresh fuel (reactions/s-atom)

\begin{tabular}{|l|l|c|}
\hline & HELIOS-2.1 & SCALE-6.1 \\
\hline
\end{tabular}




\begin{tabular}{|c|c|c|c|c|c|c|}
\hline Nuclide & Absorption & Fission & Production & Absorption & Fission & Production \\
\hline${ }^{235} \mathrm{U}$ & $9.57 \mathrm{E}-09$ & $7.49 \mathrm{E}-09$ & $1.83 \mathrm{E}-08$ & $9.72 \mathrm{E}-09$ & $7.64 \mathrm{E}-09$ & $1.86 \mathrm{E}-08$ \\
\hline${ }^{238} \mathrm{U}$ & $2.98 \mathrm{E}-10$ & $3.40 \mathrm{E}-11$ & $9.45 \mathrm{E}-11$ & $3.02 \mathrm{E}-10$ & $3.47 \mathrm{E}-11$ & $9.66 \mathrm{E}-11$ \\
\hline${ }^{239} \mathrm{~Np}$ & $5.30 \mathrm{E}-09$ & $2.22 \mathrm{E}-10$ & $6.59 \mathrm{E}-10$ & $5.42 \mathrm{E}-09$ & $2.27 \mathrm{E}-10$ & $6.73 \mathrm{E}-10$ \\
\hline${ }^{239} \mathrm{Pu}$ & $3.29 \mathrm{E}-08$ & $2.07 \mathrm{E}-08$ & $5.93 \mathrm{E}-08$ & $2.97 \mathrm{E}-08$ & $1.89 \mathrm{E}-08$ & $5.41 \mathrm{E}-08$ \\
\hline${ }^{240} \mathrm{Pu}$ & $6.81 \mathrm{E}-08$ & $2.17 \mathrm{E}-10$ & $6.65 \mathrm{E}-10$ & $6.95 \mathrm{E}-08$ & $2.21 \mathrm{E}-10$ & $6.77 \mathrm{E}-10$ \\
\hline${ }^{241} \mathrm{Pu}$ & $2.71 \mathrm{E}-08$ & $1.98 \mathrm{E}-08$ & $5.84 \mathrm{E}-08$ & $2.57 \mathrm{E}-08$ & $1.88 \mathrm{E}-08$ & $5.55 \mathrm{E}-08$ \\
\hline${ }^{241} \mathrm{Am}$ & $2.63 \mathrm{E}-08$ & $3.29 \mathrm{E}-09$ & $1.07 \mathrm{E}-09$ & $2.52 \mathrm{E}-08$ & $3.24 \mathrm{E}-09$ & $1.06 \mathrm{E}-09$ \\
\hline
\end{tabular}

Removal of neutrons by uranium isotopes is higher in SCALE-6.1 for fresh and depleted fuel, as well as fission and production (table 6 and 7). In contrast, for the plutonium isotopes, the opposite tendency is seen, whereby the calculated removal of neutrons is higher for fresh and depleted fuel by HELIOS-2.1, with the exception of ${ }^{240} \mathrm{Pu}$ in the fresh fuel case.

Table 7. Comparison of calculated reaction rates using HELIOS-2.1 and SCALE-6.1 at 60 GWd/tU (reactions/s-atom) 


\begin{tabular}{|c|c|c|c|c|c|c|}
\hline \multirow{2}{*}{ Nuclide } & \multicolumn{3}{|c|}{ HELIOS-2.1 } & \multicolumn{3}{c|}{ SCALE-6.1 } \\
\cline { 2 - 7 } & Absorption & Fission & Production & Absorption & Fission & Production \\
\hline${ }^{235} \mathrm{U}$ & $1.18 \mathrm{E}-08$ & $8.95 \mathrm{E}-09$ & $2.19 \mathrm{E}-08$ & $1.23 \mathrm{E}-08$ & $9.40 \mathrm{E}-09$ & $2.30 \mathrm{E}-08$ \\
\hline${ }^{238} \mathrm{U}$ & $4.70 \mathrm{E}-10$ & $5.68 \mathrm{E}-11$ & $1.59 \mathrm{E}-10$ & $4.68 \mathrm{E}-10$ & $5.55 \mathrm{E}-11$ & $1.55 \mathrm{E}-10$ \\
\hline${ }^{239} \mathrm{~Np}$ & $7.89 \mathrm{E}-09$ & $3.64 \mathrm{E}-10$ & $1.08 \mathrm{E}-09$ & $7.92 \mathrm{E}-09$ & $3.58 \mathrm{E}-10$ & $1.06 \mathrm{E}-09$ \\
\hline${ }^{239} \mathrm{Pu}$ & $2.92 \mathrm{E}-08$ & $1.86 \mathrm{E}-08$ & $5.35 \mathrm{E}-08$ & $2.76 \mathrm{E}-08$ & $1.78 \mathrm{E}-08$ & $5.11 \mathrm{E}-08$ \\
\hline${ }^{240} \mathrm{Pu}$ & $2.86 \mathrm{E}-08$ & $3.40 \mathrm{E}-10$ & $1.05 \mathrm{E}-09$ & $2.85 \mathrm{E}-08$ & $3.33 \mathrm{E}-10$ & $1.03 \mathrm{E}-09$ \\
\hline${ }^{241} \mathrm{Pu}$ & $2.80 \mathrm{E}-08$ & $2.07 \mathrm{E}-08$ & $6.11 \mathrm{E}-08$ & $2.76 \mathrm{E}-08$ & $2.05 \mathrm{E}-08$ & $6.04 \mathrm{E}-08$ \\
\hline${ }^{241} \mathrm{Am}$ & $2.72 \mathrm{E}-08$ & $4.41 \mathrm{E}-10$ & $1.46 \mathrm{E}-09$ & $2.64 \mathrm{E}-08$ & $4.27 \mathrm{E}-10$ & $1.42 \mathrm{E}-09$ \\
\hline
\end{tabular}

Smaller differences between the codes (in order of approximately 2\%) were observed for uranium isotopes $\left({ }^{235} \mathrm{U}\right.$ and $\left.{ }^{238} \mathrm{U}\right)$ in the fresh fuel case, and approximately $10 \%$ for ${ }^{239} \mathrm{Pu}$. The difference on fission reaction rates of ${ }^{235} U$ and ${ }^{238} U$ isotopes arises because of the difference in recoverable energy per fission. The difference is approximately $4 \%$ for ${ }^{235} \mathrm{U}$ and $6 \%$ for ${ }^{239} \mathrm{Pu}$ at $60 \mathrm{GWd} / \mathrm{tU}$ according to table 8.

Table 8. *Differences (\%) among reaction rates in the LWR case

\begin{tabular}{|c|c|c|c|c|c|c|}
\hline \multirow{2}{*}{ Nuclide } & \multicolumn{3}{|c|}{ Fresh fuel } & \multicolumn{3}{c|}{$60 \mathrm{GWd} / \mathrm{tU}$} \\
\cline { 2 - 7 } & Absorption & Fission & Production & Absorption & Fission & Production \\
\hline${ }^{235} \mathrm{U}$ & 1.57 & 2.00 & 1.64 & 4.24 & 5.03 & 5.02 \\
\hline${ }^{238} \mathrm{U}$ & 1.34 & 2.05 & 2.22 & -0.42 & -2.29 & -2.51 \\
\hline${ }^{239} \mathrm{~Np}$ & 2.26 & 2.25 & 2.12 & 0.38 & -1.65 & -1.85 \\
\hline${ }^{239} \mathrm{Pu}$ & -9.73 & -8.69 & -8.77 & -5.48 & -4.30 & -4.48 \\
\hline${ }^{240} \mathrm{Pu}$ & 2.05 & 1.84 & 1.80 & -0.35 & -2.06 & -1.90 \\
\hline${ }^{241} \mathrm{Pu}$ & -5.16 & -5.05 & -4.96 & -1.43 & -0.97 & -1.14 \\
\hline${ }^{241} \mathrm{Am}$ & -4.18 & -1.52 & -0.93 & -2.94 & -3.17 & -2.74 \\
\hline
\end{tabular}

Comparison of reaction rates per atom reveals that the removal of neutrons by plutonium isotopes is higher in HELIOS-2.1 in the LWR case.

\subsubsection{HWR case}


The calculation and comparison results of the absorption, fission, and production rates for the HWR case are presented in figures 9-11.

Table 9. Comparison of calculated reaction rates using HELIOS-2.1 and SCALE-6.1 for fresh fuel (reactions/s-atom)

\begin{tabular}{|c|c|c|c|c|c|c|}
\hline \multirow{2}{*}{ Nuclide } & \multicolumn{3}{|c|}{ HELIOS-2.1 } & \multicolumn{3}{c|}{ SCALE-6.1 } \\
\cline { 2 - 7 } & Absorption & Fission & Production & Absorption & Fission & Production \\
\hline${ }^{235} \mathrm{U}$ & $9.62 \mathrm{E}-09$ & $7.96 \mathrm{E}-09$ & $1.94 \mathrm{E}-08$ & $9.85 \mathrm{E}-09$ & $8.18 \mathrm{E}-09$ & $1.99 \mathrm{E}-08$ \\
\hline${ }^{238} \mathrm{U}$ & $1.23 \mathrm{E}-10$ & $4.86 \mathrm{E}-10$ & $1.36 \mathrm{E}-11$ & $1.24 \mathrm{E}-10$ & $5.38 \mathrm{E}-10$ & $1.50 \mathrm{E}-11$ \\
\hline${ }^{239} \mathrm{~Np}$ & $2.50 \mathrm{E}-09$ & $2.67 \mathrm{E}-11$ & $8.00 \mathrm{E}-11$ & $2.53 \mathrm{E}-09$ & $2.90 \mathrm{E}-11$ & $8.70 \mathrm{E}-11$ \\
\hline${ }^{239} \mathrm{Pu}$ & $3.30 \mathrm{E}-08$ & $2.11 \mathrm{E}-08$ & $6.04 \mathrm{E}-08$ & $2.57 \mathrm{E}-08$ & $1.69 \mathrm{E}-08$ & $4.85 \mathrm{E}-08$ \\
\hline${ }^{240} \mathrm{Pu}$ & $3.32 \mathrm{E}-08$ & $3.40 \mathrm{E}-11$ & $1.03 \mathrm{E}-10$ & $3.30 \mathrm{E}-08$ & $3.60 \mathrm{E}-11$ & $1.10 \mathrm{E}-10$ \\
\hline${ }^{241} \mathrm{Pu}$ & $2.93 \mathrm{E}-08$ & $2.14 \mathrm{E}-08$ & $6.32 \mathrm{E}-08$ & $2.52 \mathrm{E}-08$ & $1.86 \mathrm{E}-08$ & $5.47 \mathrm{E}-08$ \\
\hline${ }^{241} \mathrm{Am}$ & $2.00 \mathrm{E}-08$ & $1.39 \mathrm{E}-10$ & $4.38 \mathrm{E}-10$ & $1.74 \mathrm{E}-08$ & $1.24 \mathrm{E}-10$ & $3.90 \mathrm{E}-10$ \\
\hline
\end{tabular}

Calculated reaction rates using SCALE-6.1 are higher for uranium isotopes, as in the LWR case. Removal of neutrons by plutonium isotopes is greater in HELIOS-2.1 than in SCALE-6.1 for both fresh and depleted fuel in the HWR case.

Table 10. Comparison of calculated reaction rates using HELIOS-2.1 and SCALE-6.1 at 60 $\mathrm{GWd} / \mathrm{tU}$ (reactions/s-atom)

\begin{tabular}{|c|c|c|c|c|c|c|}
\hline \multirow{2}{*}{ Nuclide } & \multicolumn{3}{|c|}{ HELIOS-2.1 } & \multicolumn{3}{c|}{ SCALE-6.1 } \\
\cline { 2 - 7 } & Absorption & Fission & Production & Absorption & Fission & Production \\
\hline${ }^{235} \mathrm{U}$ & $4.08 \mathrm{E}-08$ & $3.43 \mathrm{E}-08$ & $8.36 \mathrm{E}-08$ & $4.62 \mathrm{E}-08$ & $3.90 \mathrm{E}-08$ & $9.49 \mathrm{E}-08$ \\
\hline${ }^{238} \mathrm{U}$ & $3.35 \mathrm{E}-10$ & $9.44 \mathrm{E}-12$ & $2.64 \mathrm{E}-11$ & $3.48 \mathrm{E}-10$ & $1.02 \mathrm{E}-11$ & $2.86 \mathrm{E}-11$ \\
\hline${ }^{239} \mathrm{~Np}$ & $7.52 \mathrm{E}-09$ & $5.12 \mathrm{E}-11$ & $1.54 \mathrm{E}-10$ & $7.96 \mathrm{E}-09$ & $5.43 \mathrm{E}-11$ & $1.63 \mathrm{E}-10$ \\
\hline${ }^{239} \mathrm{Pu}$ & $1.18 \mathrm{E}-07$ & $7.69 \mathrm{E}-08$ & $2.21 \mathrm{E}-07$ & $9.36 \mathrm{E}-08$ & $6.43 \mathrm{E}-08$ & $1.85 \mathrm{E}-07$ \\
\hline${ }^{240} \mathrm{Pu}$ & $4.32 \mathrm{E}-08$ & $6.15 \mathrm{E}-11$ & $1.88 \mathrm{E}-10$ & $4.26 \mathrm{E}-08$ & $6.42 \mathrm{E}-11$ & $1.97 \mathrm{E}-10$ \\
\hline${ }^{241} \mathrm{Pu}$ & $1.16 \mathrm{E}-07$ & $8.55 \mathrm{E}-08$ & $2.52 \mathrm{E}-07$ & $1.07 \mathrm{E}-07$ & $7.89 \mathrm{E}-08$ & $2.32 \mathrm{E}-07$ \\
\hline${ }^{241} \mathrm{Am}$ & $6.37 \mathrm{E}-08$ & $4.05 \mathrm{E}-10$ & $1.26 \mathrm{E}-09$ & $5.74 \mathrm{E}-08$ & $3.56 \mathrm{E}-10$ & $1.12 \mathrm{E}-09$ \\
\hline
\end{tabular}

Table 11. *Difference (\%) among reaction rates in the HWR case 


\begin{tabular}{|c|c|c|c|c|c|c|}
\hline \multirow{2}{*}{ Nuclide } & \multicolumn{3}{|c|}{ Fresh fuel } & \multicolumn{3}{c|}{$60 \mathrm{GWd} / \mathrm{tU}$} \\
\cline { 2 - 7 } & Absorption & Fission & Production & Absorption & Fission & Production \\
\hline${ }^{235} \mathrm{U}$ & 2.39 & 2.76 & 2.58 & 13.23 & 13.70 & 13.52 \\
\hline${ }^{238} \mathrm{U}$ & 0.81 & 10.70 & 10.29 & 3.88 & 8.05 & 8.33 \\
\hline${ }^{239} \mathrm{~Np}$ & 1.20 & 8.61 & 8.75 & 5.85 & 6.05 & 5.84 \\
\hline${ }^{239} \mathrm{Pu}$ & -22.12 & -19.91 & -19.70 & -20.68 & -16.38 & -16.29 \\
\hline${ }^{240} \mathrm{Pu}$ & -0.60 & 5.88 & 6.79 & -1.39 & 4.39 & 4.79 \\
\hline${ }^{241} \mathrm{Pu}$ & -13.99 & -13.08 & -13.45 & -7.76 & -7.72 & -7.94 \\
\hline${ }^{241} \mathrm{Am}$ & -13.00 & -10.79 & -10.96 & -9.89 & -12.10 & -11.11 \\
\hline
\end{tabular}

*(SCALE/HELIOS-1) $\times 100$

The difference of reaction rates for ${ }^{235} \mathrm{U}$ is approximately $3 \%$ for fresh fuel, but it increases to $14 \%$ for depleted fuel in the HWR case. The codes show good agreement $(<1)$ on the ${ }^{238} \mathrm{U}$ absorption reaction rate for fresh fuel, and a $4 \%$ difference for depleted fuel. However, for the fission and production reaction rates, the difference is $11 \%$ for fresh fuel and $9 \%$ for depleted fuel. The disagreement between the codes is larger for ${ }^{239} \mathrm{Pu}$, whereby a $23 \%$ difference is observed for fresh fuel and a $21 \%$ difference for depleted fuel.

\subsection{Isotopic inventory}

Isotopic material compositions of fuel change with time in the reactor due to absorption, fission, or decay. These changes affect the criticality spectrum, multiplication factor, and power distribution.

\subsubsection{LWR case}

Burn-up dependent concentrations for actinides and fission products were calculated using HELIOS-2.1 and SCALE-6.1 (TRITON) for LWR and HWR models, and compared at different burn-ups. The calculated nuclide densities at different burn-up steps in the LWR model using HELIOS-2.1 and SCALE-6.1 are summarised in tables 12 and 13. The comparison of nuclide densities at $60 \mathrm{GWd} / \mathrm{tU}$ is presented in table 14. 
Table 12. Nuclide densities calculated with HELIOS-2.1 at different burn-ups (atoms/barn-cm)

\begin{tabular}{|c|c|c|c|c|c|c|c|}
\hline \multirow{2}{*}{ Nuclide } & \multicolumn{7}{|c|}{ Burnup (GWd/tU) } \\
\cline { 2 - 8 } & 0 & 10 & 20 & 30 & 40 & 50 & 60 \\
\hline${ }^{235} \mathrm{U}$ & $1.41 \mathrm{E}-03$ & $1.16 \mathrm{E}-03$ & $9.40 \mathrm{E}-04$ & $7.56 \mathrm{E}-04$ & $6.01 \mathrm{E}-04$ & $4.73 \mathrm{E}-04$ & $3.68 \mathrm{E}-04$ \\
\hline${ }^{238} \mathrm{U}$ & $2.18 \mathrm{E}-02$ & $2.17 \mathrm{E}-02$ & $2.15 \mathrm{E}-02$ & $2.13 \mathrm{E}-02$ & $2.11 \mathrm{E}-02$ & $2.10 \mathrm{E}-02$ & $2.07 \mathrm{E}-02$ \\
\hline${ }^{239} \mathrm{Pu}$ & $1.00 \mathrm{E}-20$ & $9.42 \mathrm{E}-05$ & $1.60 \mathrm{E}-04$ & $2.05 \mathrm{E}-04$ & $2.36 \mathrm{E}-04$ & $2.59 \mathrm{E}-04$ & $2.75 \mathrm{E}-04$ \\
\hline${ }^{240} \mathrm{Pu}$ & $1.00 \mathrm{E}-20$ & $7.93 \mathrm{E}-06$ & $2.23 \mathrm{E}-05$ & $3.81 \mathrm{E}-05$ & $5.38 \mathrm{E}-05$ & $6.87 \mathrm{E}-05$ & $8.21 \mathrm{E}-05$ \\
\hline${ }^{241} \mathrm{Pu}$ & $1.00 \mathrm{E}-20$ & $3.20 \mathrm{E}-06$ & $1.35 \mathrm{E}-05$ & $2.66 \mathrm{E}-05$ & $3.98 \mathrm{E}-05$ & $5.20 \mathrm{E}-05$ & $6.29 \mathrm{E}-05$ \\
\hline${ }^{241} \mathrm{Am}$ & $1.00 \mathrm{E}-20$ & $2.65 \mathrm{E}-08$ & $2.32 \mathrm{E}-07$ & $6.58 \mathrm{E}-07$ & $1.24 \mathrm{E}-06$ & $1.88 \mathrm{E}-06$ & $2.51 \mathrm{E}-06$ \\
\hline${ }^{135} \mathrm{Xe}$ & $1.00 \mathrm{E}-20$ & $1.74 \mathrm{E}-08$ & $1.76 \mathrm{E}-08$ & $1.75 \mathrm{E}-08$ & $1.74 \mathrm{E}-08$ & $1.71 \mathrm{E}-08$ & $1.70 \mathrm{E}-08$ \\
\hline${ }^{134} \mathrm{Cs}$ & $1.00 \mathrm{E}-20$ & $4.47 \mathrm{E}-07$ & $1.80 \mathrm{E}-06$ & $3.84 \mathrm{E}-06$ & $6.39 \mathrm{E}-06$ & $9.30 \mathrm{E}-06$ & $1.24 \mathrm{E}-05$ \\
\hline${ }^{137} \mathrm{Cs}$ & $1.00 \mathrm{E}-20$ & $1.42 \mathrm{E}-05$ & $2.90 \mathrm{E}-05$ & $4.36 \mathrm{E}-05$ & $5.80 \mathrm{E}-05$ & $7.21 \mathrm{E}-05$ & $8.61 \mathrm{E}-05$ \\
\hline${ }^{95} \mathrm{Zr}$ & $1.00 \mathrm{E}-20$ & $5.14 \mathrm{E}-06$ & $5.31 \mathrm{E}-06$ & $5.13 \mathrm{E}-06$ & $4.95 \mathrm{E}-06$ & $4.80 \mathrm{E}-06$ & $4.66 \mathrm{E}-06$ \\
\hline${ }^{95} \mathrm{Mo}$ & $1.00 \mathrm{E}-20$ & $6.66 \mathrm{E}-06$ & $2.02 \mathrm{E}-05$ & $3.36 \mathrm{E}-05$ & $4.59 \mathrm{E}-05$ & $5.74 \mathrm{E}-05$ & $6.81 \mathrm{E}-05$ \\
\hline
\end{tabular}

Table 13. Nuclide densities calculated with SCALE-6.1 at different burn-ups (atoms/barn-cm)

\begin{tabular}{|c|c|c|c|c|c|c|c|}
\hline \multirow{2}{*}{ Nuclide } & \multicolumn{7}{|c|}{ Burnup (GWd/tU) } \\
\cline { 2 - 8 } & 0 & 10 & 20 & 30 & 40 & 50 & 60 \\
\hline${ }^{235} \mathrm{U}$ & $1.41 \mathrm{E}-03$ & $1.14 \mathrm{E}-03$ & $9.22 \mathrm{E}-04$ & $7.35 \mathrm{E}-04$ & $5.80 \mathrm{E}-04$ & $4.52 \mathrm{E}-04$ & $3.48 \mathrm{E}-04$ \\
\hline${ }^{238} \mathrm{U}$ & $2.18 \mathrm{E}-02$ & $2.17 \mathrm{E}-02$ & $2.15 \mathrm{E}-02$ & $2.13 \mathrm{E}-02$ & $2.11 \mathrm{E}-02$ & $2.09 \mathrm{E}-02$ & $2.07 \mathrm{E}-02$ \\
\hline${ }^{239} \mathrm{Pu}$ & $1.00 \mathrm{E}-20$ & $1.05 \mathrm{E}-04$ & $1.72 \mathrm{E}-04$ & $2.18 \mathrm{E}-04$ & $2.50 \mathrm{E}-04$ & $2.74 \mathrm{E}-04$ & $2.89 \mathrm{E}-04$ \\
\hline${ }^{240} \mathrm{Pu}$ & $1.00 \mathrm{E}-20$ & $8.55 \mathrm{E}-06$ & $2.25 \mathrm{E}-05$ & $3.78 \mathrm{E}-05$ & $5.32 \mathrm{E}-05$ & $6.76 \mathrm{E}-05$ & $7.95 \mathrm{E}-05$ \\
\hline${ }^{241} \mathrm{Pu}$ & $1.00 \mathrm{E}-20$ & $3.73 \mathrm{E}-06$ & $1.39 \mathrm{E}-05$ & $2.66 \mathrm{E}-05$ & $3.94 \mathrm{E}-05$ & $5.13 \mathrm{E}-05$ & $6.09 \mathrm{E}-05$ \\
\hline${ }^{241} \mathrm{Am}$ & $1.00 \mathrm{E}-20$ & $2.94 \mathrm{E}-08$ & $2.04 \mathrm{E}-07$ & $6.55 \mathrm{E}-07$ & $1.23 \mathrm{E}-06$ & $1.86 \mathrm{E}-06$ & $2.49 \mathrm{E}-06$ \\
\hline${ }^{135} \mathrm{Xe}$ & $1.00 \mathrm{E}-20$ & $1.71 \mathrm{E}-08$ & $1.71 \mathrm{E}-08$ & $1.69 \mathrm{E}-08$ & $1.66 \mathrm{E}-08$ & $1.63 \mathrm{E}-08$ & $1.61 \mathrm{E}-08$ \\
\hline${ }^{134} \mathrm{Cs}$ & $1.00 \mathrm{E}-20$ & $5.72 \mathrm{E}-07$ & $2.15 \mathrm{E}-06$ & $4.46 \mathrm{E}-06$ & $7.26 \mathrm{E}-06$ & $1.04 \mathrm{E}-05$ & $1.37 \mathrm{E}-05$ \\
\hline${ }^{137} \mathrm{Cs}$ & $1.00 \mathrm{E}-20$ & $1.52 \mathrm{E}-05$ & $3.02 \mathrm{E}-05$ & $4.48 \mathrm{E}-05$ & $5.93 \mathrm{E}-05$ & $7.34 \mathrm{E}-05$ & $8.73 \mathrm{E}-05$ \\
\hline${ }^{95} \mathrm{Zr}$ & $1.00 \mathrm{E}-20$ & $5.27 \mathrm{E}-06$ & $5.37 \mathrm{E}-06$ & $5.17 \mathrm{E}-06$ & $4.97 \mathrm{E}-06$ & $4.79 \mathrm{E}-06$ & $4.63 \mathrm{E}-06$ \\
\hline${ }^{95} \mathrm{Mo}$ & $1.00 \mathrm{E}-20$ & $7.41 \mathrm{E}-06$ & $2.12 \mathrm{E}-05$ & $3.46 \mathrm{E}-05$ & $4.69 \mathrm{E}-05$ & $5.83 \mathrm{E}-05$ & $6.87 \mathrm{E}-05$ \\
\hline
\end{tabular}

Comparison of calculated nuclide densities using SCALE-6.1 and HELIOS-2.1 reveal that the differences is within the expected range of $6 \%$ for ${ }^{235} \mathrm{U}$ and ${ }^{239} \mathrm{Pu}$ in the LWR case, in accordance to previous studies (table 14). 
Table 14. Comparison of calculated nuclide densities using HELIOS-2.1 and SCALE-6.1 at $60 \mathrm{GWd} / \mathrm{tU}$

\begin{tabular}{|c|c|c|c|}
\hline Nuclide & HELIOS & SCALE & Difference* (\%) \\
\hline${ }^{235} \mathrm{U}$ & $3.68 \mathrm{E}-04$ & $3.48 \mathrm{E}-04$ & -5.47 \\
\hline${ }^{238} \mathrm{U}$ & $2.07 \mathrm{E}-02$ & $2.07 \mathrm{E}-02$ & -0.05 \\
\hline${ }^{239} \mathrm{Pu}$ & $2.75 \mathrm{E}-04$ & $2.89 \mathrm{E}-04$ & 5.05 \\
\hline${ }^{240} \mathrm{Pu}$ & $8.21 \mathrm{E}-05$ & $7.99 \mathrm{E}-05$ & -3.22 \\
\hline${ }^{241} \mathrm{Pu}$ & $6.29 \mathrm{E}-05$ & $6.14 \mathrm{E}-05$ & -3.12 \\
\hline${ }^{241} \mathrm{Am}$ & $2.51 \mathrm{E}-06$ & $2.49 \mathrm{E}-06$ & -0.69 \\
\hline${ }^{135} \mathrm{Xe}$ & $1.70 \mathrm{E}-08$ & $1.61 \mathrm{E}-08$ & -5.34 \\
\hline${ }^{134} \mathrm{Cs}$ & $1.24 \mathrm{E}-05$ & $1.37 \mathrm{E}-05$ & 9.81 \\
\hline${ }^{137} \mathrm{Cs}$ & $8.61 \mathrm{E}-05$ & $8.73 \mathrm{E}-05$ & 1.36 \\
\hline${ }^{95} \mathrm{Zr}$ & $4.66 \mathrm{E}-06$ & $4.63 \mathrm{E}-06$ & -0.49 \\
\hline${ }^{95} \mathrm{Mo}$ & $6.81 \mathrm{E}-05$ & $6.87 \mathrm{E}-05$ & 0.91 \\
\hline
\end{tabular}

*(SCALE/HELIOS-1) $\times 100$

The build-ups of selected isotopes $\left({ }^{235} \mathrm{U},{ }^{238} \mathrm{U},{ }^{239} \mathrm{Pu},{ }^{240} \mathrm{Pu}\right.$ and $\left.{ }^{241} \mathrm{Pu}\right)$ are plotted in figure 5 .

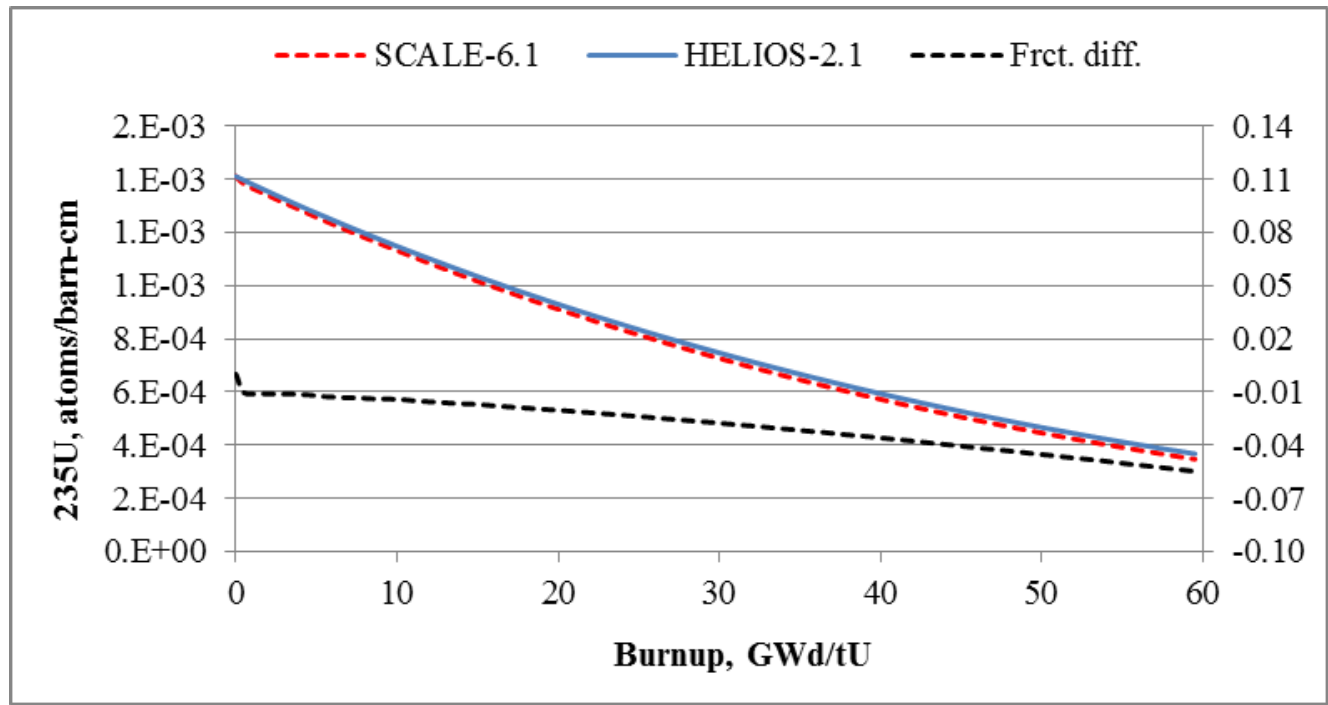

a) Burn-up dependence of the ${ }^{235} \mathrm{U}$ concentration 


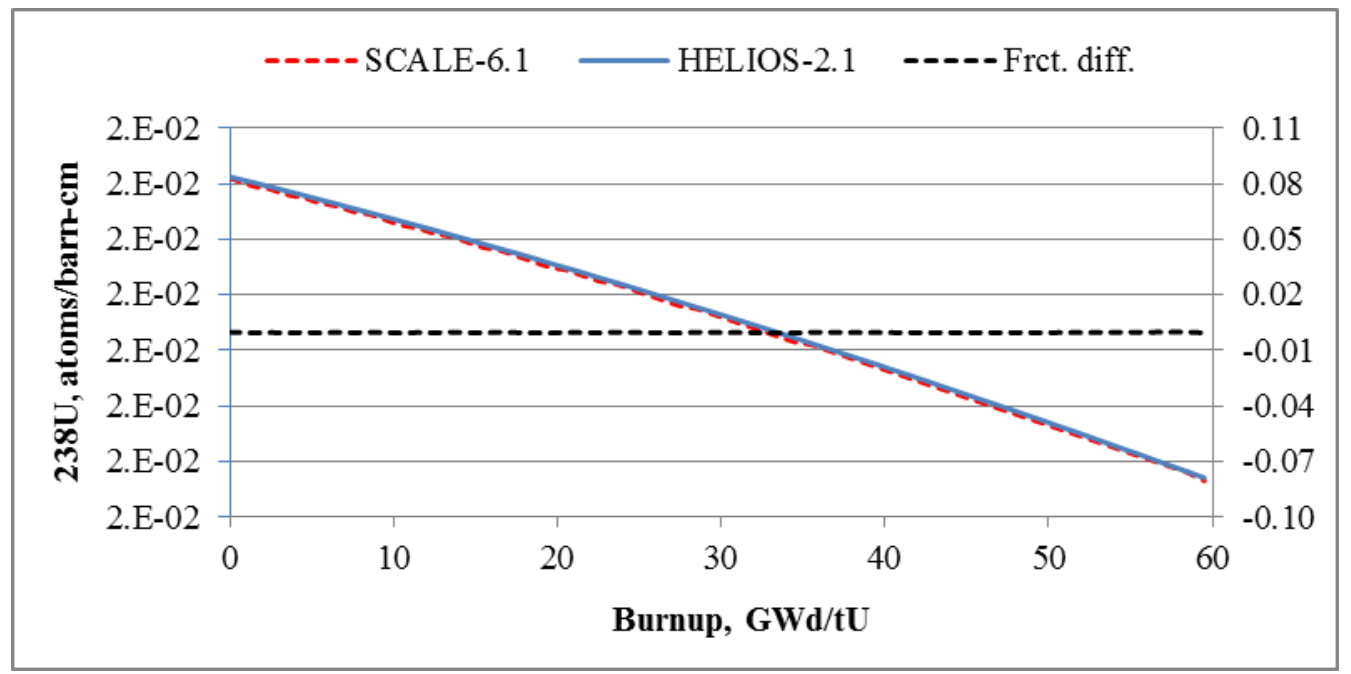

b) Burn-up dependence of the ${ }^{238} U$ concentration

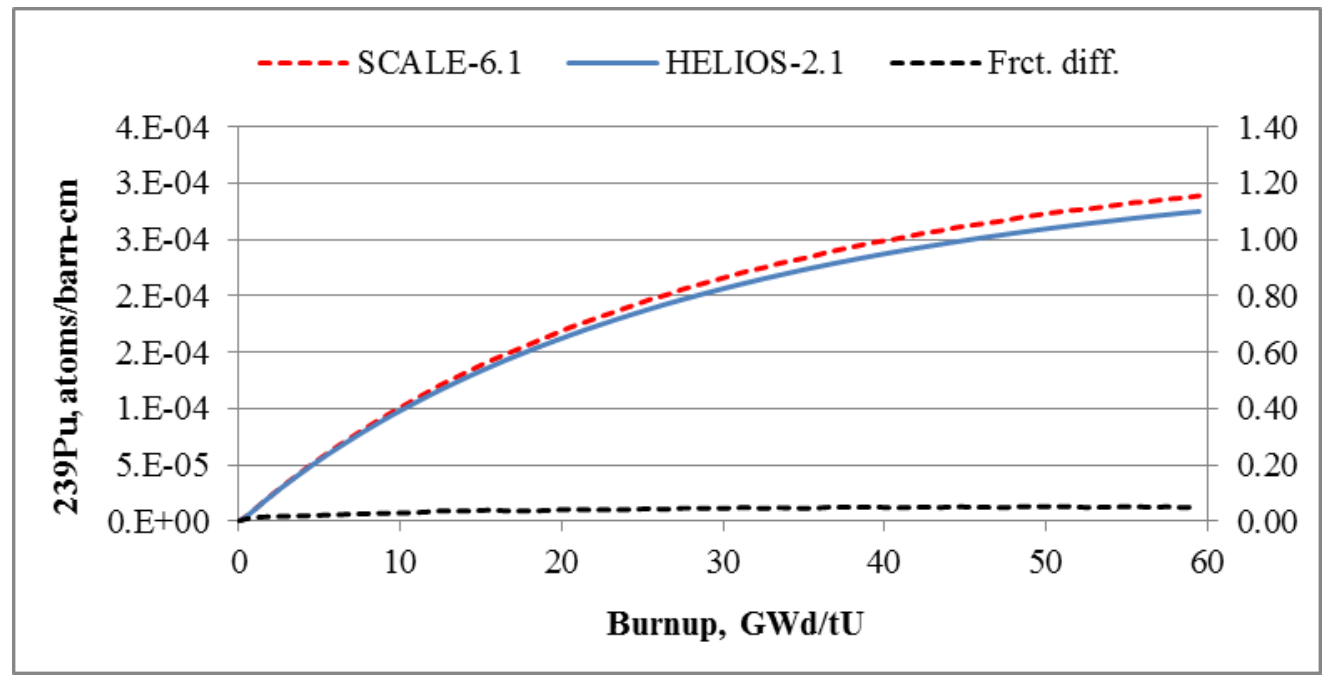

c) Burn-up dependence of the ${ }^{239} \mathrm{Pu}$ concentration

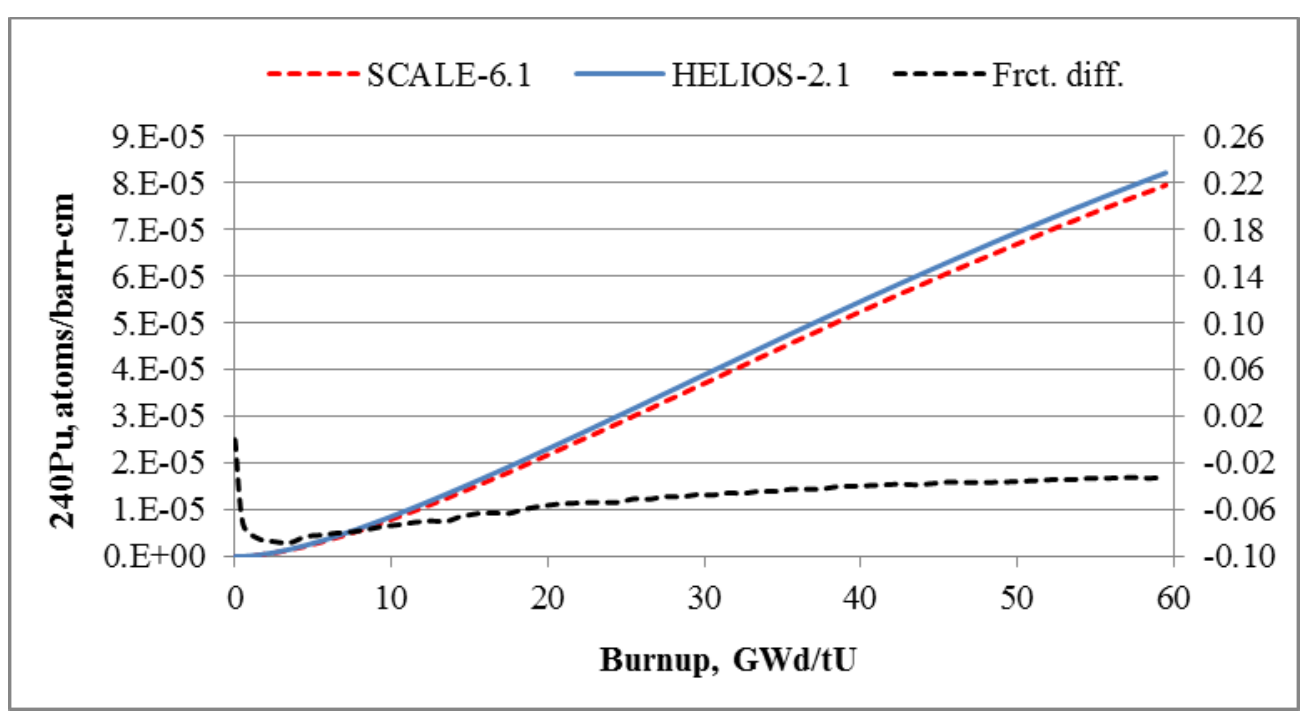

d) Burn-up dependence of the ${ }^{240} \mathrm{Pu}$ concentration 


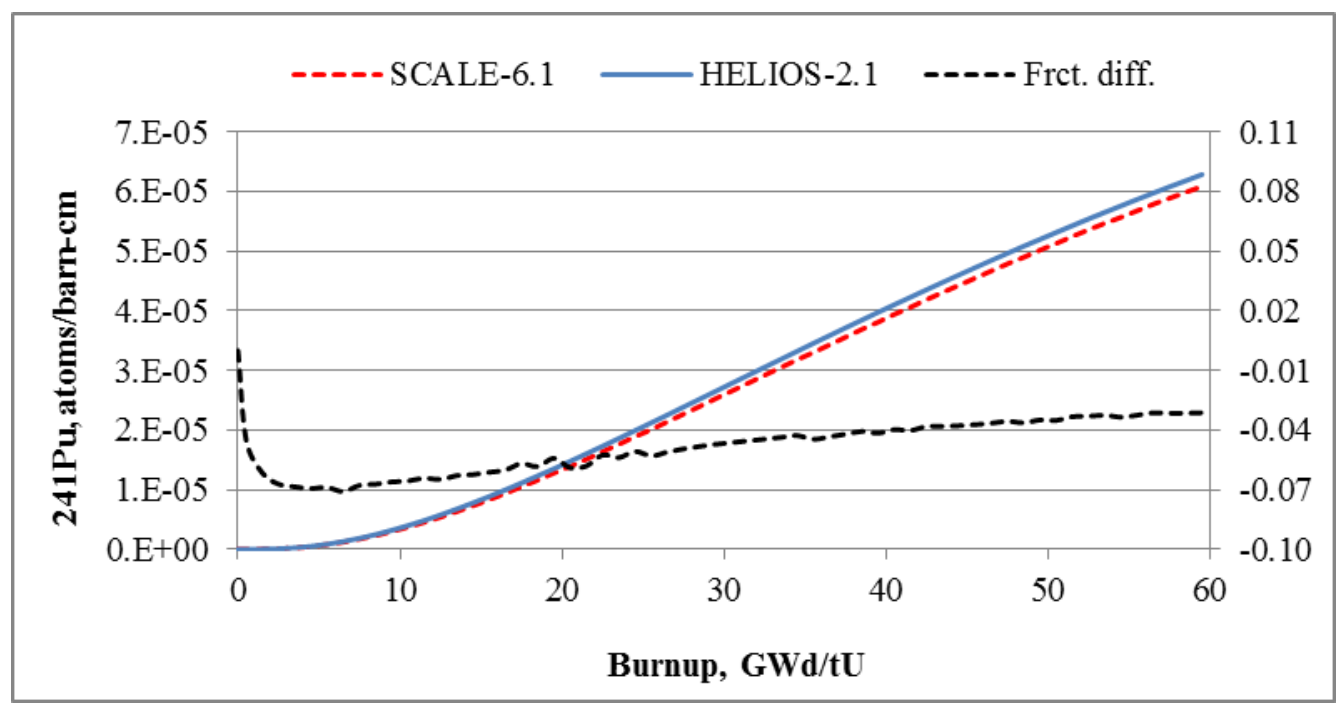

e) Burn-up dependence of the ${ }^{241} \mathrm{Pu}$ concentration

Figure 5. Burn-up dependencies of isotope concentrations (a, b, c, d and e) in the LWR case. The fractional difference was calculated as - (SCALE-HELIOS)/HELIOS

The calculated concentrations for uranium and plutonium isotopes using HELIOS-2.1 and SCALE-6.1 show good agreement in the LWR case (figure 5).

\subsubsection{HWR case}

The calculated nuclide densities in different burn-up steps using HELIOS-2.1 and SCALE-6.1 are presented in the tables 15 and 16 in the HWR case. The nuclide density comparisons are listed in table 17.

Table 15. Nuclide densities calculated with HELIOS-2.1 at different burn-ups (atoms/barn-cm)

\begin{tabular}{|c|c|c|c|c|c|c|c|}
\hline \multirow{2}{*}{ Nuclide } & \multicolumn{7}{|c|}{ Burnup (GWd/tU) } \\
\cline { 2 - 8 } & 0 & 10 & 20 & 30 & 40 & 50 & 60 \\
\hline${ }^{235} \mathrm{U}$ & $1.41 \mathrm{E}-03$ & $1.15 \mathrm{E}-03$ & $8.90 \mathrm{E}-04$ & $6.57 \mathrm{E}-04$ & $4.48 \mathrm{E}-04$ & $2.69 \mathrm{E}-04$ & $1.29 \mathrm{E}-04$ \\
\hline${ }^{238} \mathrm{U}$ & $2.18 \mathrm{E}-02$ & $2.18 \mathrm{E}-02$ & $2.17 \mathrm{E}-02$ & $2.16 \mathrm{E}-02$ & $2.15 \mathrm{E}-02$ & $2.14 \mathrm{E}-02$ & $2.13 \mathrm{E}-02$ \\
\hline${ }^{239} \mathrm{Pu}$ & $1.00 \mathrm{E}-20$ & $4.03 \mathrm{E}-05$ & $6.23 \mathrm{E}-05$ & $7.09 \mathrm{E}-05$ & $7.14 \mathrm{E}-05$ & $6.74 \mathrm{E}-05$ & $6.17 \mathrm{E}-05$ \\
\hline${ }^{240} \mathrm{Pu}$ & $1.00 \mathrm{E}-20$ & $4.54 \mathrm{E}-06$ & $1.41 \mathrm{E}-05$ & $2.49 \mathrm{E}-05$ & $3.55 \mathrm{E}-05$ & $4.49 \mathrm{E}-05$ & $5.23 \mathrm{E}-05$ \\
\hline${ }^{241} \mathrm{Pu}$ & $1.00 \mathrm{E}-20$ & $9.56 \mathrm{E}-07$ & $4.90 \mathrm{E}-06$ & $1.01 \mathrm{E}-05$ & $1.48 \mathrm{E}-05$ & $1.79 \mathrm{E}-05$ & $1.90 \mathrm{E}-05$ \\
\hline${ }^{241} \mathrm{Am}$ & $1.00 \mathrm{E}-20$ & $7.56 \mathrm{E}-09$ & $7.97 \mathrm{E}-08$ & $2.40 \mathrm{E}-07$ & $4.27 \mathrm{E}-07$ & $5.45 \mathrm{E}-07$ & $5.24 \mathrm{E}-07$ \\
\hline${ }^{135} \mathrm{Xe}$ & $1.00 \mathrm{E}-20$ & $1.12 \mathrm{E}-08$ & $9.94 \mathrm{E}-09$ & $8.44 \mathrm{E}-09$ & $6.81 \mathrm{E}-09$ & $5.15 \mathrm{E}-09$ & $3.67 \mathrm{E}-09$ \\
\hline${ }^{134} \mathrm{Cs}$ & $1.00 \mathrm{E}-20$ & $2.20 \mathrm{E}-07$ & $9.13 \mathrm{E}-07$ & $2.04 \mathrm{E}-06$ & $3.59 \mathrm{E}-06$ & $5.66 \mathrm{E}-06$ & $8.37 \mathrm{E}-06$ \\
\hline${ }^{137} \mathrm{Cs}$ & $1.00 \mathrm{E}-20$ & $1.43 \mathrm{E}-05$ & $2.91 \mathrm{E}-05$ & $4.38 \mathrm{E}-05$ & $5.82 \mathrm{E}-05$ & $7.25 \mathrm{E}-05$ & $8.66 \mathrm{E}-05$ \\
\hline${ }^{95} \mathrm{Zr}$ & $1.00 \mathrm{E}-20$ & $5.32 \mathrm{E}-06$ & $5.60 \mathrm{E}-06$ & $5.49 \mathrm{E}-06$ & $5.33 \mathrm{E}-06$ & $5.13 \mathrm{E}-06$ & $4.85 \mathrm{E}-06$ \\
\hline${ }^{95} \mathrm{Mo}$ & $1.00 \mathrm{E}-20$ & $6.87 \mathrm{E}-06$ & $2.13 \mathrm{E}-05$ & $3.59 \mathrm{E}-05$ & $4.99 \mathrm{E}-05$ & $6.30 \mathrm{E}-05$ & $7.48 \mathrm{E}-05$ \\
\hline
\end{tabular}


Table 16. Nuclide densities calculated with SCALE-6.1 at different burn-ups (atoms/barn-cm)

\begin{tabular}{|c|c|c|c|c|c|c|c|}
\hline \multirow{2}{*}{ Nuclide } & \multicolumn{7}{|c|}{ Burnup (GWd/tU) } \\
\cline { 2 - 8 } & 0 & 10 & 20 & 30 & 40 & 50 & 60 \\
\hline${ }^{235} \mathrm{U}$ & $1.41 \mathrm{E}-03$ & $1.12 \mathrm{E}-03$ & $8.48 \mathrm{E}-04$ & $6.10 \mathrm{E}-04$ & $3.98 \mathrm{E}-04$ & $2.22 \mathrm{E}-04$ & $1.04 \mathrm{E}-04$ \\
\hline${ }^{238} \mathrm{U}$ & $2.18 \mathrm{E}-02$ & $2.18 \mathrm{E}-02$ & $2.17 \mathrm{E}-02$ & $2.16 \mathrm{E}-02$ & $2.15 \mathrm{E}-02$ & $2.14 \mathrm{E}-02$ & $2.13 \mathrm{E}-02$ \\
\hline${ }^{239} \mathrm{Pu}$ & $1.00 \mathrm{E}-20$ & $4.64 \mathrm{E}-05$ & $7.23 \mathrm{E}-05$ & $8.52 \mathrm{E}-05$ & $8.87 \mathrm{E}-05$ & $8.58 \mathrm{E}-05$ & $8.07 \mathrm{E}-05$ \\
\hline${ }^{240} \mathrm{Pu}$ & $1.00 \mathrm{E}-20$ & $4.18 \mathrm{E}-06$ & $1.23 \mathrm{E}-05$ & $2.21 \mathrm{E}-05$ & $3.22 \mathrm{E}-05$ & $4.18 \mathrm{E}-05$ & $4.88 \mathrm{E}-05$ \\
\hline${ }^{241} \mathrm{Pu}$ & $1.00 \mathrm{E}-20$ & $9.60 \mathrm{E}-07$ & $4.48 \mathrm{E}-06$ & $9.31 \mathrm{E}-06$ & $1.39 \mathrm{E}-05$ & $1.72 \mathrm{E}-05$ & $1.88 \mathrm{E}-05$ \\
\hline${ }^{241} \mathrm{Am}$ & $1.00 \mathrm{E}-20$ & $7.06 \mathrm{E}-09$ & $7.11 \mathrm{E}-08$ & $2.19 \mathrm{E}-07$ & $4.07 \mathrm{E}-07$ & $5.43 \mathrm{E}-07$ & $5.48 \mathrm{E}-07$ \\
\hline${ }^{135} \mathrm{Xe}$ & $1.00 \mathrm{E}-20$ & $1.11 \mathrm{E}-08$ & $9.74 \mathrm{E}-09$ & $8.17 \mathrm{E}-09$ & $6.49 \mathrm{E}-09$ & $4.81 \mathrm{E}-09$ & $3.37 \mathrm{E}-09$ \\
\hline${ }^{134} \mathrm{Cs}$ & $1.00 \mathrm{E}-20$ & $2.71 \mathrm{E}-07$ & $1.06 \mathrm{E}-06$ & $2.30 \mathrm{E}-06$ & $4.00 \mathrm{E}-06$ & $6.22 \mathrm{E}-06$ & $9.10 \mathrm{E}-06$ \\
\hline${ }^{137} \mathrm{Cs}$ & $1.00 \mathrm{E}-20$ & $1.54 \mathrm{E}-05$ & $3.06 \mathrm{E}-05$ & $4.55 \mathrm{E}-05$ & $6.01 \mathrm{E}-05$ & $7.45 \mathrm{E}-05$ & $8.85 \mathrm{E}-05$ \\
\hline${ }^{95} \mathrm{Zr}$ & $1.00 \mathrm{E}-20$ & $5.52 \mathrm{E}-06$ & $5.75 \mathrm{E}-06$ & $5.62 \mathrm{E}-06$ & $5.43 \mathrm{E}-06$ & $5.17 \mathrm{E}-06$ & $4.80 \mathrm{E}-06$ \\
\hline${ }^{95} \mathrm{Mo}$ & $1.00 \mathrm{E}-20$ & $7.73 \mathrm{E}-06$ & $2.26 \mathrm{E}-05$ & $3.76 \mathrm{E}-05$ & $5.18 \mathrm{E}-05$ & $6.49 \mathrm{E}-05$ & $7.65 \mathrm{E}-05$ \\
\hline
\end{tabular}

Comparison of nuclide densities reveals major differences for ${ }^{235} \mathrm{U}(23 \%)$ and ${ }^{239} \mathrm{Pu}(30 \%)$ at $60 \mathrm{GWd} / \mathrm{tU}$ in the HWR case.

Table 17. Comparison of calculated nuclide densities using HELIOS-2.1 and SCALE-6.1 at $60 \mathrm{GWd} / \mathrm{tU}$

\begin{tabular}{|c|c|c|c|}
\hline Nuclide & HELIOS & SCALE & Difference* (\%) \\
\hline${ }^{235} \mathrm{U}$ & $1.29 \mathrm{E}-04$ & $9.93 \mathrm{E}-05$ & -19.21 \\
\hline${ }^{238} \mathrm{U}$ & $2.13 \mathrm{E}-02$ & $2.13 \mathrm{E}-02$ & -0.06 \\
\hline${ }^{239} \mathrm{Pu}$ & $6.17 \mathrm{E}-05$ & $8.04 \mathrm{E}-05$ & 30.69 \\
\hline${ }^{240} \mathrm{Pu}$ & $5.23 \mathrm{E}-05$ & $4.91 \mathrm{E}-05$ & -6.68 \\
\hline${ }^{241} \mathrm{Pu}$ & $1.90 \mathrm{E}-05$ & $1.88 \mathrm{E}-05$ & -1.48 \\
\hline${ }^{241} \mathrm{Am}$ & $5.24 \mathrm{E}-07$ & $5.48 \mathrm{E}-07$ & 4.48 \\
\hline${ }^{135} \mathrm{Xe}$ & $3.67 \mathrm{E}-09$ & $3.37 \mathrm{E}-09$ & -7.99 \\
\hline${ }^{134} \mathrm{Cs}$ & $8.37 \mathrm{E}-06$ & $9.10 \mathrm{E}-06$ & 8.68 \\
\hline${ }^{137} \mathrm{Cs}$ & $8.66 \mathrm{E}-05$ & $8.85 \mathrm{E}-05$ & 2.25 \\
\hline${ }^{95} \mathrm{Zr}$ & $4.85 \mathrm{E}-06$ & $4.80 \mathrm{E}-06$ & -1.02 \\
\hline${ }^{95} \mathrm{Mo}$ & $7.48 \mathrm{E}-05$ & $7.65 \mathrm{E}-05$ & 2.35 \\
\hline
\end{tabular}

$*$ (SCALE/HELIOS-1) $\times 100$

Figure 6 demonstrates the build-ups of uranium and plutonium isotopes with depletion in the HWR case. 


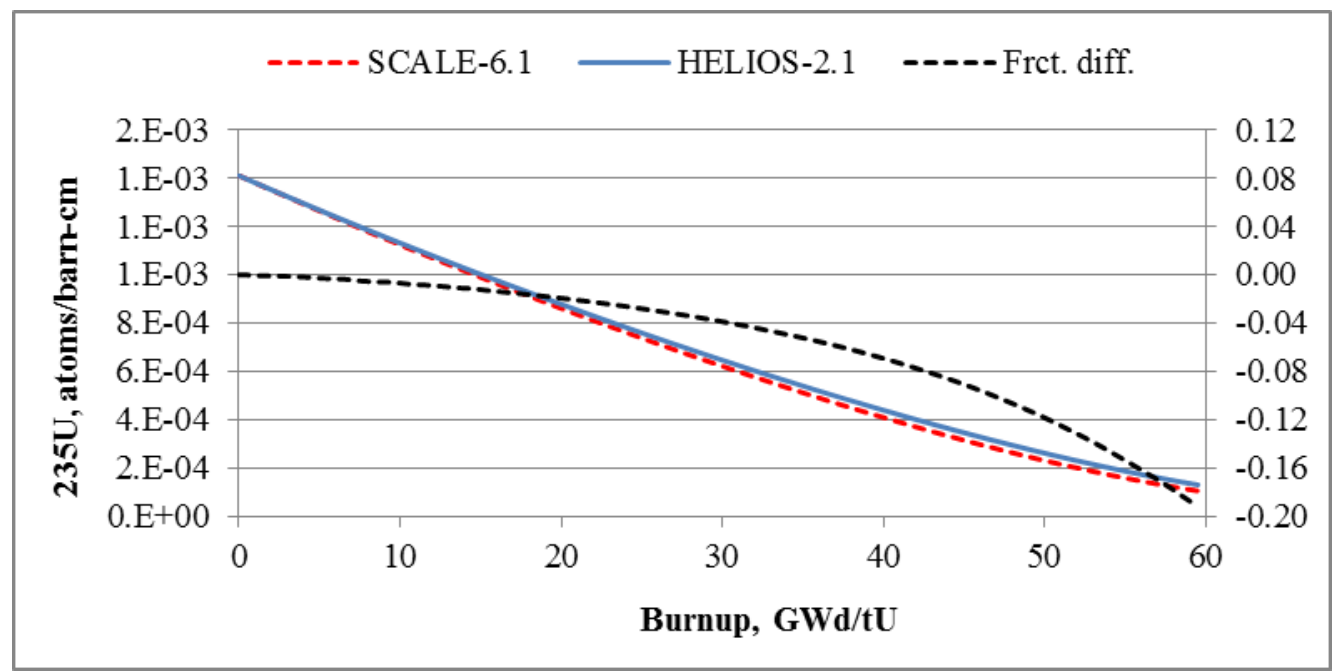

a) Burn-up dependence of the ${ }^{235} U$ concentration

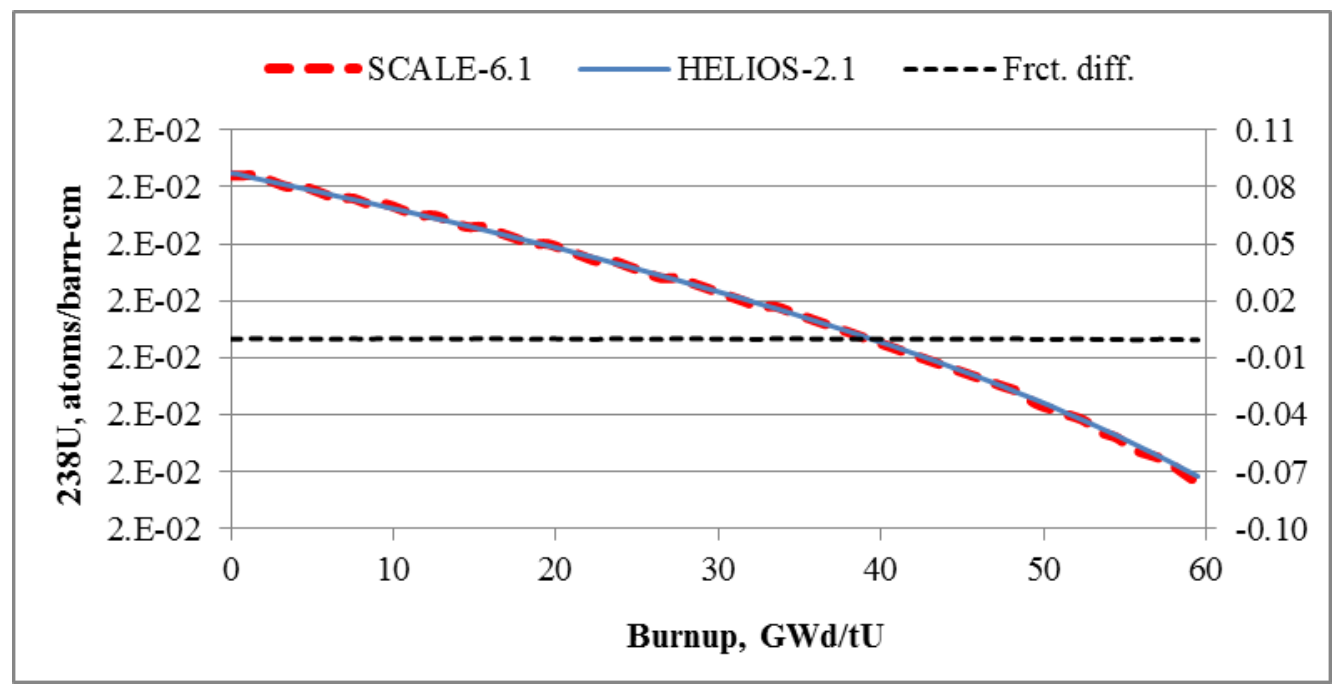

b) Burn-up dependence of the ${ }^{238} U$ concentration

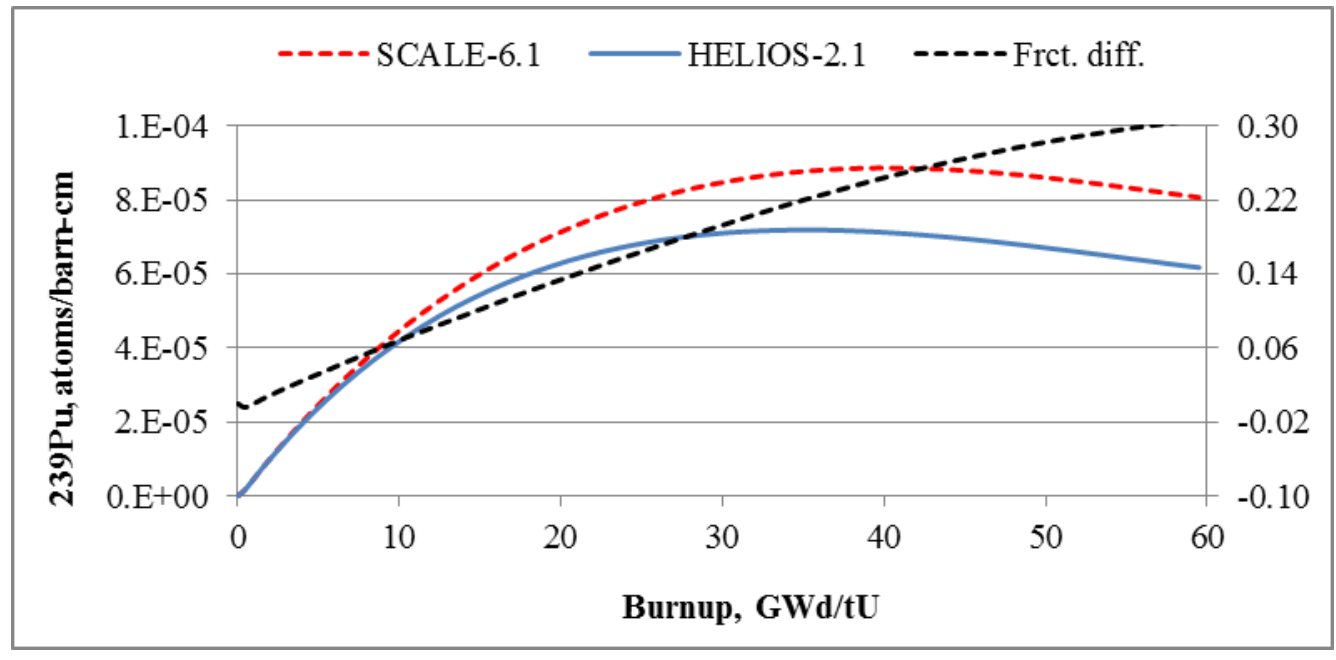

c) Burn-up dependence of the ${ }^{239} \mathrm{Pu}$ concentration 


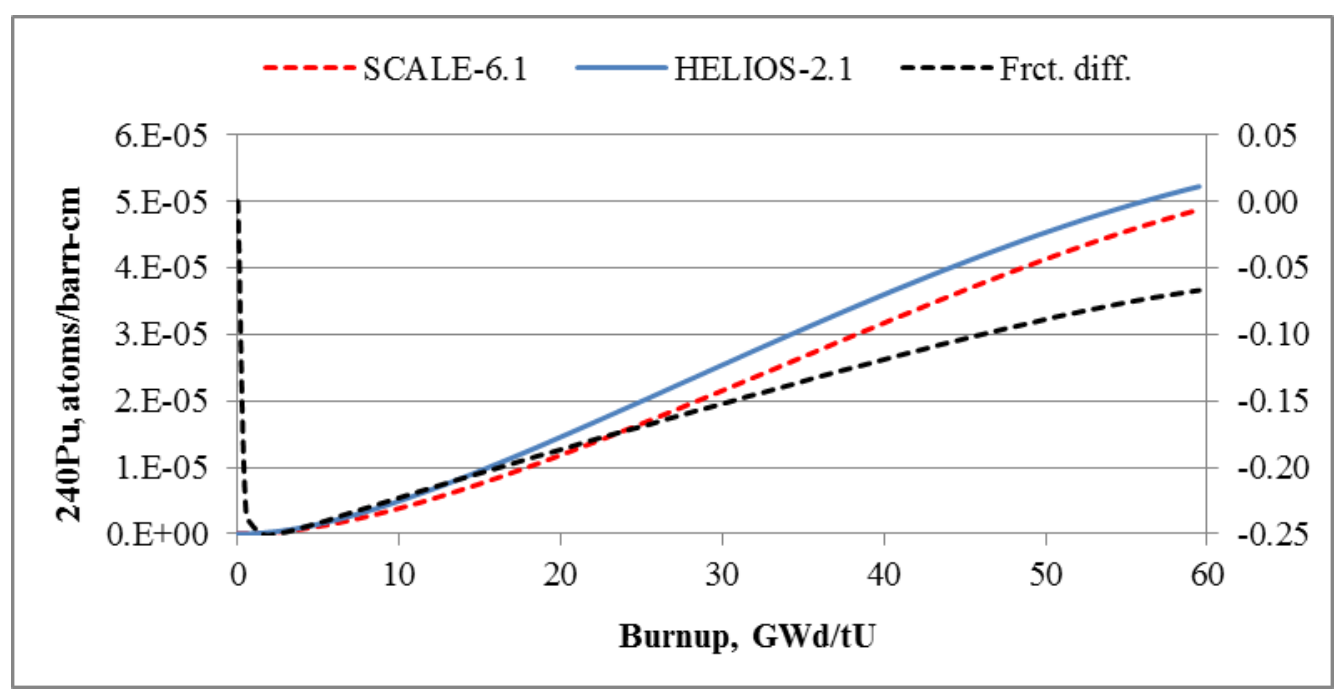

d) Burn-up dependence of the ${ }^{240} \mathrm{Pu}$ concentration

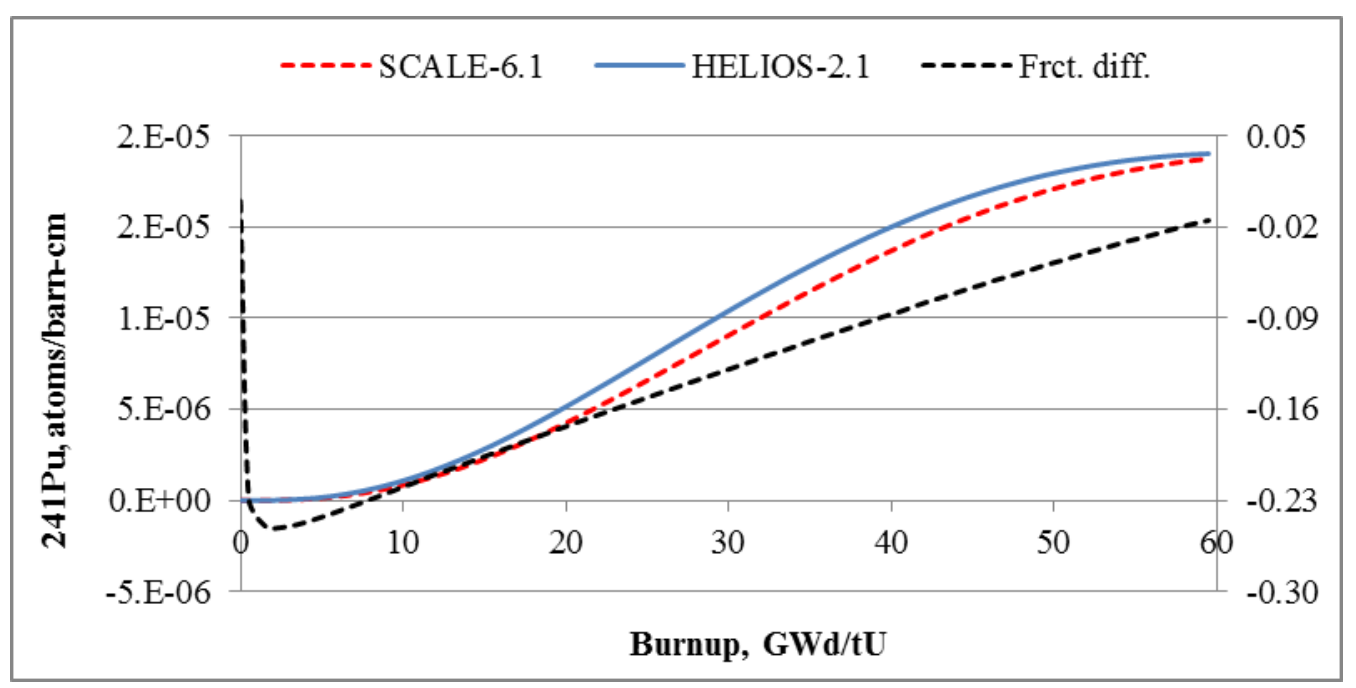

e) Burn-up dependence of the ${ }^{241} \mathrm{Pu}$ concentration

Figure 6. Burn-up dependencies of isotope concentrations (a, b, c, d and e) in the HWR case. The fractional difference was calculated as - (SCALE-HELIOS)/HELIOS

The differences observed in the uranium and plutonium concentration comparison in table 17 are also observed in the graphs of figure 6 . The largest disagreement between the codes is observed for ${ }^{239} \mathrm{Pu}$ with a noted $30 \%$ difference and for ${ }^{235} \mathrm{U}$ with a $20 \%$ difference.

\subsubsection{Origen of ${ }^{239} \mathrm{Pu}$ discrepancy}

To explain the large differences seen in the concentration comparison of plutonium isotopes in the HWR case, the neutron fission cross section, neutron flux spectrum and reaction rates are inspected in detail.

Firstly, calculated ${ }^{239} \mathrm{Pu}$ fission cross sections using HELIOS-2.1 and SCALE-6.1 were compared with ENDF/B-VII.0 data. Comparisons revealed that HELIOS-2.1 and SCALE-6.1 fission cross sections are in good agreement with each other and ENDF/B-VII.0 data, as shown in figure 7. 


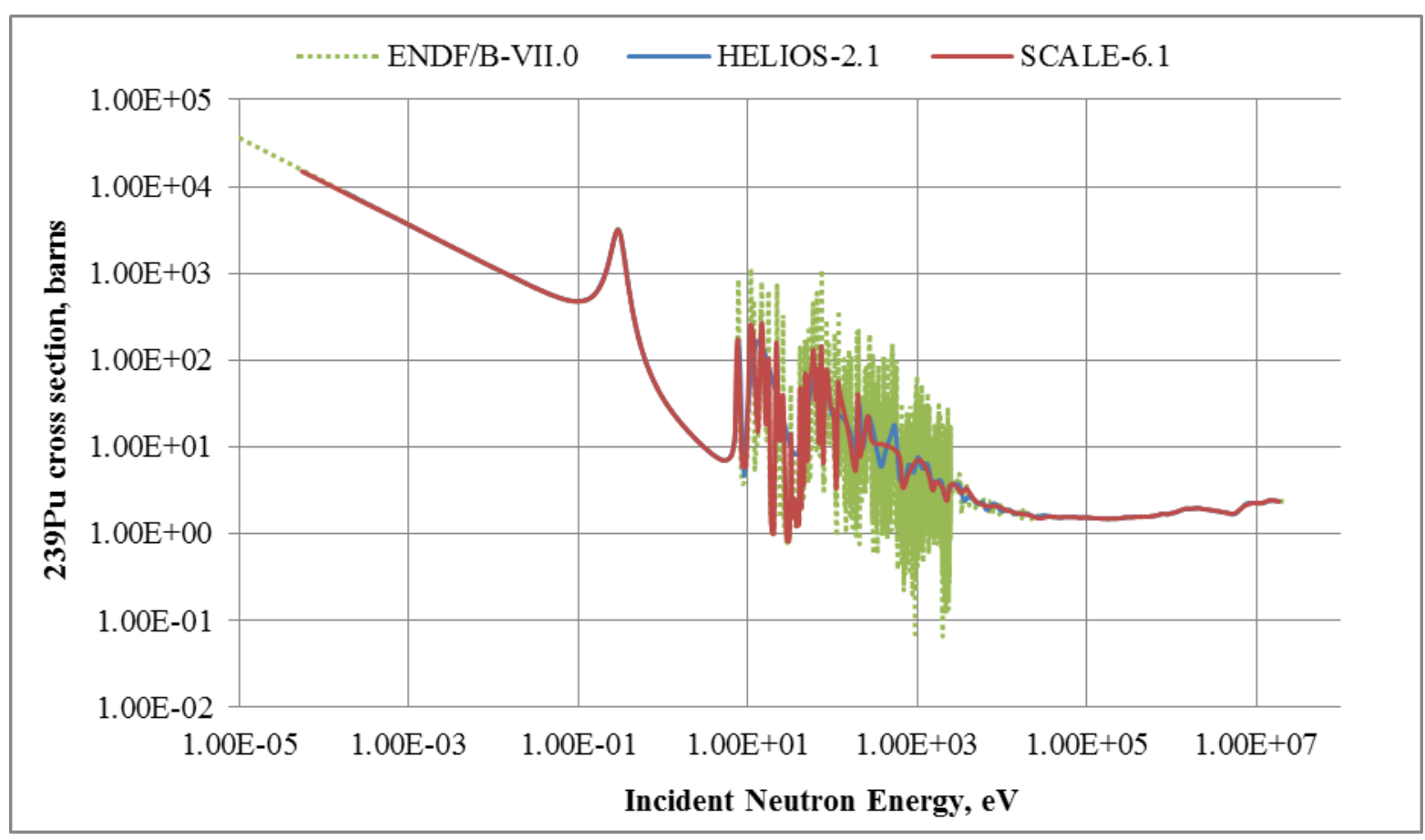

Figure 7. ${ }^{239} \mathrm{Pu}$ fission cross section comparison

Secondly, the neutron flux spectrum was divided into various regions and reaction rates were calculated per region in the LWR and HWR cases. The comparison results are summarised for the fast $(\mathrm{E}>1 \mathrm{MeV})$, resonance $(5 \mathrm{eV}<\mathrm{E}<3 \mathrm{keV})$, and thermal $(\mathrm{E}<0.626 \mathrm{eV})$ regions in tables 18 and 19. Other (intermediate) regions are ignored, because their contribution to the total reaction rates is insignificant. The thermal region has the largest contribution (94\%) to the total reaction rates, while the resonance and fast regions are approximately $4 \%$ and $1 \%$, respectively.

Table 18. Comparison of ${ }^{239 P u}(n, f)$ reaction rates in the LWR case

\begin{tabular}{|l|c|c|c|}
\hline \multicolumn{1}{|c|}{$\begin{array}{c}\text { Neutron energy } \\
\text { regions }\end{array}$} & HELIOS-2.1 & SCALE-6.1 & $\begin{array}{c}\text { Difference* } \\
(\%)\end{array}$ \\
\hline Fast region & $8.92 \mathrm{E}-01$ & $8.98 \mathrm{E}-01$ & 0.72 \\
\hline Resonance region & $5.52 \mathrm{E}+00$ & $5.34 \mathrm{E}+00$ & -3.28 \\
\hline Thermal region & $4.76 \mathrm{E}+01$ & $4.19 \mathrm{E}+01$ & -12.02 \\
\hline Total & $5.55 \mathrm{E}+01$ & $4.96 \mathrm{E}+01$ & -10.61 \\
\hline
\end{tabular}

The comparison results (tables 18 and 19) show that the largest difference for ${ }^{239} \mathrm{Pu}$ is seen in the thermal region for both cases, with $12 \%$ in the LWR and $31 \%$ in the HWR cases. The fast region elicited the smallest difference of $0.72 \%$ in the LWR and a difference of $6 \%$ in the HWR cases. The difference in the total reaction rates is approximately $11 \%$ for the LWR and $30 \%$ for the HWR cases. 
Table 19. Comparison of ${ }^{239} \mathrm{Pu}(\mathrm{n}, \mathrm{f})$ reaction rates in the HWR case

\begin{tabular}{|l|c|c|c|}
\hline \multicolumn{1}{|c|}{$\begin{array}{c}\text { Neutron energy } \\
\text { regions }\end{array}$} & HELIOS-2.1 & SCALE-6.1 & $\begin{array}{c}\text { Difference* } \\
(\%)\end{array}$ \\
\hline Fast region & $4.31 \mathrm{E}-01$ & $4.05 \mathrm{E}-01$ & -5.90 \\
\hline Resonance region & $7.36 \mathrm{E}+00$ & $6.56 \mathrm{E}+00$ & -10.81 \\
\hline Thermal region & $2.20 \mathrm{E}+02$ & $1.52 \mathrm{E}+02$ & -30.81 \\
\hline Total & $2.30 \mathrm{E}+02$ & $1.61 \mathrm{E}+02$ & -29.87 \\
\hline *(SCALE/HELIOS-1) $\times 100$
\end{tabular}

Comparative analyses of calculated ${ }^{239} \mathrm{Pu}(\mathrm{n}, \mathrm{f})$ reaction rates per region using HELIOS-2.1 and SCALE-6.1 suggest that the neutron thermalisation process is treated differently by these codes.

Lastly, calculated reaction rates per lethargy for ${ }^{239} \mathrm{Pu}$ using HELIOS-2.1 and SCALE-6.1 are plotted in the HWR case and displayed in figure 8.

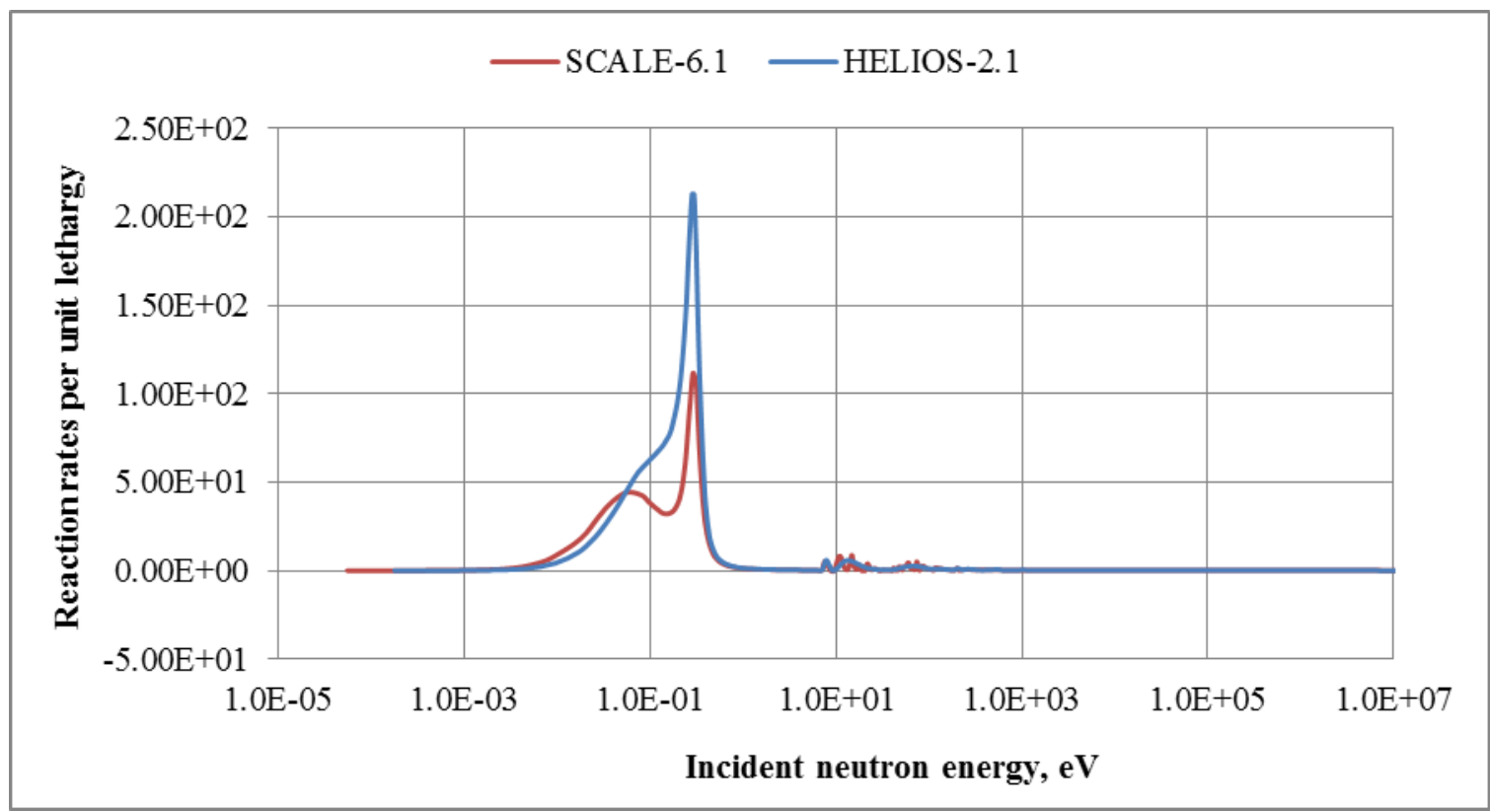

Figure 8. Comparison of calculated reaction rates for ${ }^{239} \mathrm{Pu}$ using Helios-2.1 and Scale-6.1 in the HWR case

Figure 8 shows clearly the disagreement in the low energy resonance of the ${ }^{239} \mathrm{Pu}(\mathrm{n}, \mathrm{f})$ reaction in the thermal region elicited by HELIOS-2.1 and SCALE-6.1.

Comparison of the neutron fission cross section, neutron flux spectrum and reaction rates for ${ }^{239} \mathrm{Pu}$ revealed that significant differences in the thermal neutron spectrum result in differences in the ${ }^{239} \mathrm{Pu}$ reaction rate. This is owing to the presence of a low energy resonance for fission capture. This discrepancy between codes results in significantly different isotopic distributions with fuel burn-up. We speculate that this difference is more visible in the HWR case as the thermalisation process is more important than the LWR case. Thermal neutrons have a much longer lifetime and undergo more collisions in the HWR case than the LWR case.

\section{Conclusions}


In this study, the calculated results of the HELIOS-2.1 and SCALE-6.1 codes are analysed and compared using pin-cell models in the LWR and HWR cases. The calculations are performed using the same ENDF/B-VII.0 nuclear data library, but different energy group structures. HELIOS-2.1 used the 177 neutron energy group, while SCALE-6.1 used the 238 neutron energy group.

Comparison of kinf has shown that the codes are in good agreement in both the LWR and HWR cases. The difference for fresh fuel is approximately $1 \%$ in both the LWR and HWR cases, which is consistent with previous studies. For depleted fuel, the difference is approximately $1.5 \%$ for the LWR case and $0.5 \%$ for the HWR case.

The study of the neutron flux spectrum has shown that larger differences are observed in thermal and epithermal regions. The cause of these differences was investigated by comparing the reaction rates for different isotopes and incident neutron energies. It is concluded that, discrepancies observed in the LWR and HWR flux distributions might be due to the different numbers and structures of neutron energy groups. In fast neutron regions, the codes had a similar number of groups, but in resonance and thermal regions, SCALE-6.1 had more energy groups compared to HELIOS-2.1.

The study of the LWR case has revealed that the differences in the reaction rates between the compared codes for fresh fuel were approximately $2 \%$ for ${ }^{235} \mathrm{U}$, and $10 \%$ for ${ }^{239} \mathrm{Pu}$. However, for depleted fuel, the difference increased up to $5 \%$ for ${ }^{235} \mathrm{U}$, and decreased to $5 \%$ for ${ }^{239} \mathrm{Pu}$. In the HWR case, the difference of the compared reaction rates for ${ }^{235} \mathrm{U}$ was $3 \%$ for fresh fuel, but it increased to $14 \%$ for depleted fuel. The codes showed a better agreement for the elicited ${ }^{238} \mathrm{U}$ absorption reaction rates for fresh fuel and for depleted fuel both in the LWR and HWR cases. The disagreement between codes was larger for ${ }^{239} \mathrm{Pu}$, with $23 \%$ for fresh fuel and $21 \%$ for depleted fuel in the HWR case.

Comparison of calculated nuclide densities using HELIOS-2.1 and SCALE-6.1 revealed that the difference was approximately $6 \%$ for both ${ }^{235} \mathrm{U}$ and ${ }^{239} \mathrm{Pu}$ in the LWR case, which agreed with reported results in previous studies. However, the differences between the codes were $20 \%$ for ${ }^{235} \mathrm{U}$ and $30 \%$ for the ${ }^{239} \mathrm{Pu}$ in the HWR case. Preliminary investigation of the ${ }^{239} \mathrm{Pu}$ fission cross section, neutron flux and reaction rates, showed that the two codes mainly disagreed on the calculation of the neutron thermalisation process.

It is concluded that a more extensive research is required to model the thermalisation process in the HWR case. This process needs to be investigated further to determine the root cause. Possible causes could be the neutron group structure, cross section condensation, treatment of up-scatter, angle dependence of scatter, and spatial homogenisation during source iterations.

\section{Acknowledgements}

This work was supported by the Islamic Development Bank (IDB) Merit Scholarship Program (MSP) for High Technology.

\section{References}


Michaele C. Brady, Burnup-Credit Criticality Benchmark. Part 1-B. Isotopic Prediction, NEA/NSC/DOC (92)10, November 1992

https://www.oecd-nea.org/science/docs/1991/neacrp-l-1991-337.pdf

M. Brady, M. Takano, H. Okuno, M. D. Dehart, A. Nouri, E. Sartori, Findings of the OECD/NEA Study on Burnup Credit, Proc. of intl. conf. on the Physics of Reactors, PHYSOR 96, September 1996

http://www.oecd-nea.org/dbprog/BUC-GENERAL1.pdf

Benchmark on the VENUS-2 MOX core measurements, NEA/NSC/DOC (2000)7, OECD/NEA, 2000

https://www.oecd-nea.org/science/docs/2000/nsc-doc2000-7.pdf

K. Kamenov, D. Hristov, WWER-1000 spent fuel nuclide inventory at the Kozloduy NPP, Proceedings of the seventeenth Symposium of Atomic Energy Research, Hungary, 2007

http://www.iaea.org/inis/collection/NCLCollectionStore/_Public/39/077/39077469.pdf?r= $\underline{1}$

W.S. Charlton, W.D. Stanbro, R.T. Perry, Comparisons of HELIOS, ORIGEN2 and Monteburns calculated ${ }^{241} \mathrm{Am}$ and ${ }^{243} \mathrm{Am}$ concentrations to measured values for PWR, BWR and VVER spent fuel, Journal of Nuclear Science and Technology, Vol.37, No. 7, p.615623, July 2000

HELIOS-2 methods, SSP-11/452 Rev 1, Version-2.1, Studsvik, 2012

M. B. Chadwick, et al., ENDF/B-VII.0: Next Generation Evaluated Nuclear Data Library for Nuclear Science and Technology, Nuclear Data Sheets 107, 2006

http://www.sciencedirect.com/science/article/pii/S0090375206000871

R. E. MacFarlane and A. C. Kahler, Methods for processing ENDF/B-VII with NJOY, Nuclear Data Sheets 111, July 2010

https://t2.lanl.gov/nis/publications/methods.pdf

SCALE: A Comprehensive Modelling and Simulation Suite for Nuclear Safety Analysis and Design, ORNL/TM-2005/39, Version 6.1, ORNL, 2011

M. A. Jessee, M. D. DeHart, TRITON: a multipurpose transport, depletion, and sensitivity and uncertainty analysis module, ORNL/TM-2005/39, Version 6.1, ORNL, 2011

M. L. Williams, D. F. Hollenbach, CENTRM: a one-dimensional neutron transport code for computing pointwise energy spectra, ORNL/TM-2005/39, Version 6.1, ORNL, 2011 
M. A. Jessee, M. D. Dehart, NEWT: a new transport algorithm for two-dimensional discrete-ordinates analysis in non-orthogonal geometries, ORNL/TM-2005/39, Version 6.1, ORNL, 2011

I. C. Gauld, ORIGEN-S: depletion module to calculate neutron activation, actinide transmutation, fission product generation, and radiation source terms, ORNL/TM-2005/39, Version 6.1, ORNL, 2011

R. J. Ellis, VENUS-2 MOX core benchmark: results of ORNL calculations using HELIOS1.4 - revised report, ORNL/TM-2000/180/R1, May 2001

https://rsicc.ornl.gov/FMDP/ellis_tm2000_180_r1.pdf 